\title{
Effect of exogenously-applied abscisic acid, putrescine and hydrogen peroxide on drought tolerance of barley
}

\author{
Ernest Skowron ${ }^{1}$ (D) $\cdot$ Magdalena Trojak ${ }^{1}$ (D)
}

Received: 24 May 2020 / Accepted: 27 October 2020 / Published online: 23 November 2020

(C) The Author(s) 2020

\begin{abstract}
The objective of this study was to identify the effect of abscisic acid (ABA), putrescine (Put) and hydrogen peroxide $\left(\mathrm{H}_{2} \mathrm{O}_{2}\right)$ foliar pre-treatment on drought tolerance of barley. Despite water limitation, ABA-sprayed plants preserved increased water content, photosynthetic efficiency of PSII ( $\Phi$ PSII) and $\mathrm{CO}_{2}$ assimilation rate $\left(P_{\mathrm{n}}\right)$ compared to untreated stressed plants. The ABA-treated plants presented also the lowest rate of lipid peroxidation (MDA), lowered the rate of PSII primary acceptor reduction $(1-\mathrm{qP})$ and increased the yield of regulated energy dissipation (NPQ) with higher accumulation of PGRL1 (PROTON GRADIENT REGULATION LIKE1) protein. These plants preserved a similar level of photochemical efficiency and the rate of electron transport of PSII $\left(E^{2} R_{I I}\right)$ to the well-watered samples. The significantly less pronounced response was observed in Put-sprayed samples under drought. Additionally, the combined effects of drought and $\mathrm{H}_{2} \mathrm{O}_{2}$ application increased the $1-\mathrm{qP}$ and quantum yield of non-regulated energy dissipation in PSII ( $\Phi N O)$ and reduced the accumulation of Rubisco activase (RCA). In conclusion, ABA foliar application allowed to balance water retention and preserve antioxidant capacity resulting in efficient photosynthesis and the restricted risk of oxidative damage under drought. Neither hydrogen peroxide nor putrescine has been able to ameliorate drought stress as effectively as ABA.
\end{abstract}

Keywords Abscisic acid $\cdot$ Drought stress $\cdot$ Hydrogen peroxide $\cdot$ Oxidative stress $\cdot$ Putrescine

\section{Introduction}

Water availability is a crucial factor limiting plant growth in natural arid and semi-arid areas (Evenari et al. 1976) as well as in agricultural regions, constantly expanded to meet the food needs of the growing population (Khush 2001; Mega et al. 2019). Repeatedly occurring episodes of water shortage during the growing season reduce plant growth, flowering, pollination, fertilization and grain development influencing quality and quantity of yield. Drought limits the cell division, reduces the size of the leaf blade, slows down or even inhibits shoot elongation and drastically reduces stomatal conductance, lim-

Ernest Skowron

skowron.ernest@gmail.com

Magdalena Trojak

magdalenamariatrojak@gmail.com

1 Department of Environmental Biology, The Jan Kochanowski University, Uniwersytecka 7, 25-406 Kielce, Poland iting the uptake and transport of water, ions and gas exchange (Farooq et al. 2009). Reduced $\mathrm{CO}_{2}$ diffusion to the site of carboxylation is the main cause of decreased photosynthesis under drought (Flexas et al. 2009). The water shortage also influences photosynthesis within reduced chlorophyll content and the oxygen-evolving complex (OEC) capacity (Chen et al. 2016). Moreover, thylakoid membranes are distorted as a consequence of the enhanced production of deleterious reactive oxygen species (ROS) (Cruz de Carvalho 2008). Decreased stomatal conductance and disturbed linear electron flow inhibits Calvin cycle activation, resulting in overreduction of stroma $\mathrm{NADP}^{+}$pool and higher leakage of electrons to $\mathrm{O}_{2}$ via Mehler reaction (Tamburino et al. 2017). This mechanism is responsible for the superoxide radical production, scavenged to hydrogen peroxide via $\mathrm{Cu} / \mathrm{Zn}$ superoxide dismutase $(\mathrm{Cu} / \mathrm{Zn} \mathrm{SOD})$. At the same time, when chloroplastic $\mathrm{CO}_{2}$ concertation is decreased under drought, the photorespiration becomes predominant in $\mathrm{H}_{2} \mathrm{O}_{2}$ generation, perturbing the redox regulatory state of the plant cells and antioxidant pools (Laxa et al. 2019). Enzyme catalase (CAT), essential for the conversion of $\mathrm{H}_{2} \mathrm{O}_{2}$ to water and oxygen, exerts most of its 
activity in the peroxisomes, where it counteracts $\mathrm{H}_{2} \mathrm{O}_{2}$ generation during photorespiration (Melandri et al. 2020). It has been documented (Alexander et al. 2019) that higher activity of CAT under stress conditions is associated with increased drought tolerance of the plant. Although the accumulation of ROS is generally harmful to cells (Czarnocka and Karpiński 2018), under moderate leaf-water deficits, ROS production is tightly regulated by antioxidant enzymes and non-enzymatic scavengers, thus ROS functions predominantly as the alarm signals that trigger defense response (Cruz de Carvalho 2008). However, prolonged drought stress accompanied by reduction of water content by 35-80\% leads to depletion of photosystem II (PSII) core proteins (Giardi et al. 1996) and degradation of Lhcb5, Lhcb6, and PsbQ proteins.

Plants have a variety of physiological and biochemical responses to drought, among them phytohormones such as abscisic acid. ABA plays a role in the plant water status regulation by managing guard cell turgor, plant growth, the expression of dehydration response genes (Zhang et al. 2006), and the accumulation of osmotic compounds such as proline (Pro), polyamines (PAs) and soluble sugars (Sezgin et al. 2018). The hormone activates antioxidant enzymes e.g., SOD and CAT, and attenuates the rate of membrane lipids peroxidation ( $\mathrm{Li}$ et al. 2011). The earliest plant response to water deficit is also the rapid stomatal closure regulated by a complex network of signaling pathways with ABA and jasmonates. The ABA has traditionally been considered as a major stomatal movement regulator, especially under drought (Daszkowska-Golec and Szarejko 2013). Drought-induced stomatal closure, regulated by the ABA signal, serves as the first line of defense against drought (Li et al. 2020) and controls the rates of water loss and $\mathrm{CO}_{2}$ intake (Cardoso et al. 2020). Therefore, exogenously applied ABA has been successfully used as an effective regulator of drought-stress response (Brito et al. 2020; Gai et al. 2020). For this reason, we analyzed the basis of ABA-improved drought resistance in barley.

Moreover, as $\mathrm{H}_{2} \mathrm{O}_{2}$ is the key molecule regulating ABAinduced stomatal closure (Desikan et al. 2004), the influence of its application under drought has been also tested in the present study. The exogenous $\mathrm{H}_{2} \mathrm{O}_{2}$ application has been successfully employed to induce stomatal closure (Sun et al. 2016) and accumulation of molecules, such as Pro and PAs (Terzi et al. 2014) improving drought tolerance in plants (de Sousa et al. 2016). PAs, including tested putrescine (Put) spermidine and spermine (Mattoo et al. 2010), are small, ubiquitous nitrogenous compounds (Gupta et al. 2012), and regulate the concentration of ABA (Cuevas et al. 2008) and contrariwise - ABA modulates the expression of PAs-biosynthetic genes and their accumulation in response to drought stress (Pottosin and Shabala 2014). Increased PAs concentration is important for the hydraulic conductivity of guard-cell (Alcázar et al. 2010) and has a positive effect on photosynthetic efficiency due to membrane-stabilizing abilities and antioxidant properties of PAs (Pottosin and Shabala 2014).

Alleviation of drought stress in crops such as analyzed barley is crucial because stress triggers the premature onset of leaf senescence (Janack et al. 2016). The prolonged lifespan of leaves is particularly important for cereals' flag leaf contributing to grain filling (Lee et al. 2017). Barley is an economically important plant that ranks fourth among cereals. It is preferentially used as a feed grain, as raw material for brewing and as food (Sreenivasulu et al. 2008). However, as barley is grown worldwide is often subjected to extreme drought stress that significantly affects production (Guo et al. 2009). It has been previously documented that spring forms of barley, despite their major role in agriculture due to short vegetation period, suffer from soil water limitation as a result of the poorly developed root system, that makes them far more sensitive to drought episodes than winter ones (Pecio and Wach 2015). Thus, for drought-response analyses spring cultivar Carina of barley has been chosen as sensitive to water dehydration.

The objective of the present study was the effect of abscisic acid, putrescine and hydrogen peroxide foliar pre-treatment in barley exposed to the water shortage. Efforts have also been made to know that which one acts more efficiently to improve drought tolerance. For this purpose, we tested the hypothesis that applied regulators alleviate drought stress through (1) higher water retention realized by stomatal closure and increased osmoprotectants accumulation, (2) protection of photosynthetic apparatus with an altered level of proteins engaged in cyclic electron flow (CEF) around photosystem I (PSI) and NPQ activation and (3) increased antioxidant capacity. To this end, we analyzed water retention (RWC) and proline accumulation, the photosynthetic machinery condition (chlorophylls content, PSII photochemical and non-photochemical activity, PsbO protein level), gas exchange (net photosynthetic rate- $P_{\mathrm{n}}$ and stomatal conductance- $g_{\mathrm{s}}$ ), Rubisco LSU and Rubisco activase (RCA) contents, as well as the level of PGRL1 (PROTON GRADIENT REGULATION LIKE1) and NdhS protein (subunit $\mathrm{S}$ of the chloroplast NADH dehydrogenaselike complex), involved in the alternative routes of electron transport from PSI and the antioxidant defense of plants during drought (SOD, CAT, $\mathrm{H}_{2} \mathrm{O}_{2}, \mathrm{MDA}$ ).

\section{Materials and methods}

\section{Plant material and growth conditions}

The experiments were carried out on the spring barley cultivar (Hordeum vulgare L. cv. Carina), selected as a droughtsensitive compared to drought-tolerant winter form Lomerit (Supplementary Material Figs. S1, S2; Table S1). Sterilized 
seeds were sown individually in plastic pots (volume $\approx$ $\left.0.5 \mathrm{dm}^{3}\right)$ containing a mixture of soil and sand $(2: 1, v / \mathrm{v}$, $\mathrm{pH} 6.0-6.5)$ and $1 \mathrm{~g}$ compound fertilizer $\left(\mathrm{N}: \mathrm{P}_{2} \mathrm{O}_{5}: \mathrm{K}_{2} \mathrm{O}=\right.$ 5: 2: 6) added to each pot as base fertilizer. The seedlings were grown in chambers under the uniform white light with a maximum intensity of $130 \mu \mathrm{mol} \mathrm{m} \mathrm{m}^{-2}$. The photoperiod was $16 / 8 \mathrm{~h}$ (day/night) and the average temperature was maintained at $26 / 25^{\circ} \mathrm{C}$ with a relative humidity kept at 50 $60 \%$. The plants were watered every day with tap water until the drought. Measurement of physiological and biochemical parameters was performed using the third fully expanded leaf.

\section{Experimental systems and treatments used}

Drought stress of the 30-day-old plants was imposed by the cessation of watering for seven consecutive days. The plants were divided into five groups and treated as follows: (1) the control plants (CT) continually irrigated with tap water, sprayed with distilled water; (2) drought-stress treatment (D), sprayed with distilled water; (3) the plants subjected to drought stress with $100 \mu \mathrm{M}$ ABA applied as a foliar spray (D + ABA); (4) the plants subjected to drought stress with $5 \mathrm{mM} \mathrm{H}_{2} \mathrm{O}_{2}$ applied as a foliar spray (D+ $\mathrm{H}_{2} \mathrm{O}_{2}$ ); (5) the plants subjected to drought stress with $100 \mu \mathrm{M}$ Put applied as a foliar spray (D + Put). The optimum concentration of the applied solutions was based on our earlier preliminary experiment. All plants were sprayed twice - on the first and the fourth day of the experiment, each time with $5 \mathrm{ml}$ of water/proper compound per plant. The application scheme proposed was selected to induce and sustain plant acclimation to drought stress, therefore compounds were foliar applied just before and during the water limitation. The time of the second treatment was selected based on the analyzed soil water content when it dropped below $70 \%$ of the initial value (data not shown).

Abscisic acid [( \pm )-ABA] (Sigma-Aldrich, St. Louis, USA) solutions were prepared by dissolving the stock solution of ABA in methanol $(40 \mathrm{mg} / 1 \mathrm{ml})$ in distilled water. Putrescine (1,4-diaminobutane) (Sigma-Aldrich) solutions were prepared in distilled water. Hydrogen peroxide (Sigma-Aldrich) solutions were prepared by dissolving the $30 \%$ stock solution in distilled water. Solutions were immediately foliage-applied with a hand sprayer. Each foliar treatment consisted of an additional $0.01 \%(\mathrm{v} / \mathrm{v})$ Tween-20 (Bio-Rad, Hercules, USA) as a surfactant and $0.067 \%(\mathrm{v} / \mathrm{v})$ methanol solution. The compounds were applied at the 14th growth stage of the Zadoks decimal code (Zadoks et al. 1974). Therefore, imposed drought stress mimicked this triggered repeatedly by environmental cues during the seedling early growth stage.

\section{Determination of soil volumetric water contents and leaf relative water content}

Changes in the soil moisture during the study were tracked by the Moisture Meter Type HH2 with a ThetaProbe Soil Moisture Sensor-ML2x (Delta-T Devices Ltd., Cambridge, UK), each time placing the probe to a depth of $5 \mathrm{~cm}$. The soil volumetric water contents (SVWC) before the drought was maintained at approximately $26 \%$, corresponding to soil water content at $80 \%$ of field capacity (FC). FC of soil was calculated on a weight basis. During drought control plants were irrigated to FC (26\% SVWC), and waterdeficit plants were not irrigated throughout the experiment. Leaf water status was determined by measuring relative water content (RWC), using $1 \mathrm{~cm}$ leaf fragments cut out from the middle of the blade and weighted for fresh weight (FW) determination. Samples were collected from 8:0010:00 h. To assess turgid weight (TW), fresh leaf fragments were incubated in distilled water for $24 \mathrm{~h}$ at $4{ }^{\circ} \mathrm{C}$, weighted and then dried for the next $48 \mathrm{~h}$ at $90{ }^{\circ} \mathrm{C}$ to determine the dry weight (DW). RWC was calculated as follows (Ishibashi et al. 2011):

$\mathrm{RWC}=[(\mathrm{FW}-\mathrm{DW}) /(\mathrm{TW}-\mathrm{DW})] \times 100$

Analyses were performed in ten replicates for each treatment.

\section{Estimation of proline}

The concentration of free proline was determined as described by Giannakoula et al. (2008), with an optimized acidninhydrin reaction step proposed by Shabnam et al. (2016). $0.5 \mathrm{~g}$ of fresh leaf material was homogenized in $5 \mathrm{ml}$ of $80 \%$ $(v / v)$ ethanol, transferred into glass vials and heated at $60{ }^{\circ} \mathrm{C}$ for $30 \mathrm{~min}$. The extract was then filtered through Whatman No. 2 filter paper, diluted with $80 \%$ (v/v) ethanol up to $10 \mathrm{ml}$, sealed and mixed thoroughly. Next, $1 \mathrm{ml}$ of the aqueous alcohol extract was transferred into test tubes and $2 \mathrm{ml}$ of reaction mix: $1.25 \%(w / v)$ ninhydrin, $60 \%(\mathrm{v} / \mathrm{v})$ glacial acetic acid, $20 \%$ (v/v) ethanol, was added. The tubes were mixed, pierced with the lids and placed in a water bath at $100{ }^{\circ} \mathrm{C}$ for $30 \mathrm{~min}$. The reaction mixture was cooled to room temperature (RT) and the absorbance of the proline-ninhydrin condensation product was determined spectrophotometrically (UV VIS Helios Gamma, Thermo Spectronic, Waltham, USA) at $508 \mathrm{~nm}$. For quantification, a calibration curve was obtained using proline standard solutions prepared in $80 \%(\mathrm{v} / \mathrm{v})$ ethanol added to the reaction mix. Data were calculated as $\mu$ moles per gram dry weight ( $\mu \mathrm{mol} \mathrm{g}^{-1} \mathrm{DW}$ ) as proposed by Sarker and Oba (2018). The assay was performed in ten replicates for each treatment. 


\section{Determination of photosynthetic pigments content and chlorophyll stability index}

The collected leaves were ground to a fine powder in liquid nitrogen and chlorophyll $a, b(\mathrm{Chl} a, b)$ and carotenoids were extracted with dimethyl sulfoxide (DMSO) in a ratio of $1.5 \mathrm{ml}$ DMSO per $10 \mathrm{mg}$ of plant tissue. The samples were incubated for $3 \mathrm{~h}$ at $65^{\circ} \mathrm{C}$ and the absorbance was determined at 480 , 649 and $665 \mathrm{~nm}$, according to the method described by Wellburn (1994). The chlorophyll stability index (CSI) was determined according to Terzi and Kadioglu (2006) and calculated as follows:

$\mathrm{CSI}=($ total $\mathrm{Chl} a+b$ after treatment $/$ total $\mathrm{Chl} a+b$ before treatment $)$ $\times 100$

Data were calculated as mg per gram dry weight $\left(\mathrm{mg} \mathrm{g}^{-1}\right.$ DW). The assay was performed in ten replicates for each treatment.

\section{Measurement of chlorophyll fluorescence (ChF) in- duction kinetics}

$\mathrm{ChF}$ induction kinetics of control and drought-stressed barley leaves was performed using pulse amplitude modulated (PAM) fluorometer (Maxi IMAGING-PAM M-Series, Walz, Effeltrich, Germany). The minimal fluorescence level (Fo) with all PSII reaction centers open was measured by the measuring modulated blue light $(\lambda=450 \mathrm{~nm})$, which was sufficiently low $\left(0.01 \mu \mathrm{mol} \mathrm{m}^{-2} \mathrm{~s}^{-1}\right)$ not to induce any significant variable fluorescence. The maximal fluorescence level (Fm) with all PSII reaction centers closed was determined by a $0.8 \mathrm{~s}$ saturating pulse at $2700 \mu \mathrm{mol} \mathrm{m} \mathrm{s}^{-2}$ in $30 \mathrm{~min}$ dark-adapted leaves. Then, the leaf was continuously illuminated with blue actinic light $\left(186 \mu \mathrm{mol} \mathrm{m} \mathrm{m}^{-2} \mathrm{~s}^{-1}\right)$. After about $4 \mathrm{~min}$, the steady-state value of fluorescence $(\mathrm{Fs})$ was thereafter recorded and a second saturating pulse at $2700 \mu \mathrm{mol} \mathrm{m}^{-2} \mathrm{~s}^{-1}$ was imposed to determine maximal fluorescence level in the lightadapted state $\left(\mathrm{Fm}^{\prime}\right)$. The maximum quantum yield of PSII ( $\mathrm{Fv} /$ fm), actual photochemical efficiency of PSII (ФPSII), the quantum yield of regulated energy dissipation in PSII $(\Phi N P Q)$ and non-regulated energy dissipation in PSII $(\Phi \mathrm{NO})$, non-photochemical quenching (NPQ) and the electron transport rate of PSII $\left(E^{2} R_{I I}\right)$ were measured. Chlorophyll fluorescence decrease ratio $\left(\mathrm{R}_{\mathrm{Fd}}\right)$ defined as $\mathrm{ChF}$ decrease from maximum (Fm) to steady-state fluorescence (Fs) was estimated in 3-5 min under continuous saturating light ( $396 \mu \mathrm{mol} \mathrm{m}^{-2} \mathrm{~s}^{-1}$ ) (based on light response curve, data not shown) according to Lichtenthaler et al. (2005) as follows:

$\mathrm{R}_{\mathrm{Fd}}=(\mathrm{Fm}-\mathrm{Fs}) / \mathrm{Fs}$
The excitation pressure on PSII $(1-\mathrm{qP})$ was estimated as has been shown by Dahal et al. (2017). The electron transport rate of PSII $\left(\right.$ ETR $\left._{\text {II }}\right)$ was calculated based on the measured $\Phi P S I I$, the incident photon flux density of blue actinic light $\left(\mathrm{PAR}_{\mathrm{AL}}\right)$ and the absorptivity (Abs.), defined as the fraction of the incident light absorbed by the leaf sample first illuminated with red (R) and then with near-infrared (NIR).

$$
\begin{gathered}
\operatorname{ETR}_{\mathrm{II}}\left(\mu \mathrm{mol} \text { electrons } \mathrm{m}^{-2} \mathrm{~s}^{-1}\right)=0.5 \times \Phi \mathrm{PSII} \times \mathrm{PAR}_{\mathrm{AL}} \times \text { Abs. } \\
\text { Abs. }=1-\mathrm{R} / \mathrm{NIR}
\end{gathered}
$$

All measurements were carried out on the third fully expanded leaves and were performed between 8:00-11:00. Analyses of $\mathrm{ChF}$ were performed in six replicates for each treatment.

\section{Leaf gas-exchange measurements}

The net photosynthetic rate $\left(P_{\mathrm{n}}\right)$ and stomatal conductance $\left(g_{\mathrm{s}}\right)$ of leaves were monitored from 8:30-11:30 h using a $\mathrm{Li}$ 6400XT Portable Photosynthesis System (LI-COR, Inc., Lincoln, USA) with $2 \times 3 \mathrm{~cm}$ LED light source 6400-02B chamber. Cuvette conditions were maintained at a growthlike light intensity of $130 \mu \mathrm{mol}$ photons $\mathrm{m}^{-2} \mathrm{~s}^{-1}$, air relative humidity of $60 \%$, leaf temperature of $25^{\circ} \mathrm{C}, 400 \mu \mathrm{mol} \mathrm{mol}^{-1}$ of external $\mathrm{CO}_{2}$ concentration and gas flow rate of $500 \pm$ $2 \mu \mathrm{mol} \mathrm{s}^{-1}$. Gas-exchange measurements on the first (Day 1) and fourth day (Day 4) were determined $4 \mathrm{~h}$ after water/ solution application. Analyses were performed in ten replicates for each treatment.

\section{Leaf protein extraction and preparation. The analysis of Rubisco large subunit accumulation}

Leaf soluble proteins were extracted with Plant Total Protein Extraction Kit (Sigma-Aldrich) according to the manufacturer's instructions, gel-resolved and stained with Coomassie Brilliant Blue (CBB) for quantifying the amount of Rubisco large subunit (LSU) or electrophoretically transferred to nitrocellulose membranes for Western Blot (WB) analyses as proposed by Martin et al. (2005). In brief, $200 \mathrm{mg}$ of the leaf powder was washed with methanol working solution and acetone, protected from proteolysis with protease inhibitor cocktail. Purified tissue pellet has been used for total protein extraction with chaotropic protein reagent. Protein content was estimated according to Bradford (1976) using Coomassie reagent (ThermoFisher, Waltham, USA) and bovine serum albumin as a standard. Samples mixed with $2 \mathrm{X}$ Laemmli Sample Buffer (4\% SDS, 10\% 2-mercaptoethanol, $20 \%$ glycerol, $0.004 \%$ bromophenol blue, $0.125 \mathrm{M}$ Tris- $\mathrm{HCl}$, pH 6.8) (Bio-Rad) were incubated at $95{ }^{\circ} \mathrm{C}$ for $5 \mathrm{~min}$, cooled down to RT, spun down shortly, loaded and separated onto gels. For PGRL1 analysis sample buffer without a reducing 
agent has been used and protein samples were incubated at $70{ }^{\circ} \mathrm{C}$ for $10 \mathrm{~min}$ as proposed by Hertle et al. (2013).

For CBB staining protein content was standardized to $20 \mu \mathrm{g}$ per lane and loaded onto precast $10 \%$ TGX polyacrylamide gels (Bio-Rad). Four replicates of each treatment were analyzed. Gels were stained with Bio-Safe ${ }^{\mathrm{TM}}$ Coomassie Stain (Bio-Rad). The quantification of the protein bands of the CBB stained gels (for Rubisco LSU) was made using densitometric analysis (ImageJ v.1.52, National Institutes of Health, Maryland, USA) (Tercé-Laforgue et al. 2004). The relative amount of Rubisco LSU protein was calculated using as a maximum the value measured in $\mathrm{CT}$ plants.

\section{Western blot analysis of photosynthetic proteins}

Optimized amounts of extracted proteins were loaded onto precast 4-20\% gradient TGX polyacrylamide gels (Bio-Rad) and run with a constant voltage of $200 \mathrm{~V}$ for $20 \mathrm{~min}$. Separated proteins were transferred to nitrocellulose membranes $(0.45 \mu \mathrm{m}$ or $0.2 \mu \mathrm{m}$ pore size; Bio-Rad) by semi-dry electroblotting $\left(1.5 \mathrm{~mA}\right.$ per $\left.\mathrm{cm}^{2}, 20 \mathrm{~min}\right)$. Air-dried blots were blocked with 5\% non-fat dry milk blocking reagent ( $1 \mathrm{~h}, \mathrm{RT})$ (Bio-Rad) and incubated with primary antibodies against RCA (AS10 700; 1:5000), PsbO (AS06 142-33; 1:5000), PGRL1 (AS10 725; 1:1000), NdhS (AS16 4066; 1:1000) and eEF1a (Elongation factor 1-alpha; AS10 934; 1:5000) (Agrisera, Vännäs, Sweden) overnight at $4{ }^{\circ} \mathrm{C}$, washed in Tween-TBS buffer (TTBS; 0.05\% Tween 20, $20 \mathrm{mM}$ Tris, $500 \mathrm{mM} \mathrm{NaCl}$ ) and incubated with a horseradish peroxidase-conjugated secondary antibody (AS09 602; 1:5000-1:10000) for $1 \mathrm{~h}$ at RT with agitation. The blots were washed in TTBS and developed for 5-10 min with colorimetric detection using Pierce ${ }^{\mathrm{TM}}$ DAB Substrate Kit (3,3'-diaminobenzidine tetrahydrochloride) (Thermo Fisher Scientific, Waltham, USA). The quantification of the protein bands of the WB membranes visualized with DAB was made using densitometric analysis (ImageJ v.1.52) (Tercé-Laforgue et al. 2004). RCA signal was estimated from both $\alpha$ - and $\beta$-isoform bands visualized on the membrane, as an overall RCA content $\left(\mathrm{RCA}_{\text {total }}\right)$. PGRL1 signal was estimated either as an overall protein content $\left(\mathrm{PGRL} 1_{\text {total }}\right)$ or as the ratio of individual signal for reduced (PGRL1 $1_{\text {red }}$ ) and oxidized (PGRL1 $\left.1_{\text {ox }}\right)$ monomer. To investigate RCA, PsbO and eEF1a $5 \mu \mathrm{g}$, and for PGRL1 and NdhS $25 \mu \mathrm{g}$ of total protein was separated on gels. eEF1a was used as a loading control. The samples were analyzed in threefold. The relative amount of proteins was calculated using as a maximum the value measured in CT plants.

\section{Determination of antioxidant enzyme activities}

The activity of SOD (EC 1.15.1.1) was determined using the modified method of Xu et al. (2008). $200 \mathrm{mg}$ of leaf powder was homogenized with $1 \mathrm{ml}$ of an ice-cold $100 \mathrm{mM}$ phosphate buffer (pH 7.8) containing 1 mM EDTA (pH 8.0) and 5\% (w/ v) polyvinylpolypyrrolidone (PVPP). The homogenates were centrifuged at $10,000 \times g$ for $30 \mathrm{~min}, 4{ }^{\circ} \mathrm{C}$. Then $40 \mu \mathrm{l}$ of each enzyme extract was mixed with $100 \mu \mathrm{l}$ of $0.75 \mathrm{mM}$ nitroblue tetrazolium (NBT), $2 \mu$ l of 0.5 M EDTA (pH 8.0) and $20 \mu$ l of $0.1 \mathrm{mM}$ riboflavin. Because of the photosensitivity of the solution, the procedure was carried out under low light. The samples containing the reaction solution were irradiated under a set of fluorescent light tubes of $40 \mu \mathrm{mol} \mathrm{m}^{-2} \mathrm{~s}^{-1}$ for $10 \mathrm{~min}$. The absorbance of the irradiated and non-irradiated samples was determined at $560 \mathrm{~nm}$. One unit of enzyme activity was taken as that amount of enzyme, which reduced the absorbance reading to $50 \%$ in comparison with tubes lacking the enzyme (Sarker and Oba 2018). The assay was performed in six replicates for each treatment.

The activity of CAT (EC 1.11.1.6) was determined according to the method of Aebi (1984) with some modifications (Lu et al. 2013). In brief, $20 \mu \mathrm{l}$ of enzyme extract was added to $405 \mu \mathrm{l}$ of $50 \mathrm{mM}$ potassium phosphate buffer $(\mathrm{pH}=7.0)$ and $250 \mu \mathrm{l}$ of water. After $5 \mathrm{~min}$ pre-incubation at $26^{\circ} \mathrm{C} 750 \mu \mathrm{l}$ of $10 \mathrm{mM} \mathrm{H}_{2} \mathrm{O}_{2}$ was added to start the reaction. The decomposition of $\mathrm{H}_{2} \mathrm{O}_{2}$ was followed directly by the decrease in absorbance at $240 \mathrm{~nm}$ (GENESYS 10S UV-Vis, Thermo Scientific Waltham, USA). Enzyme activity was computed by calculating the amount of $\mathrm{H}_{2} \mathrm{O}_{2}$ decomposed, every $20 \mathrm{~s}$ for $3 \mathrm{~min}$ at $26{ }^{\circ} \mathrm{C}$. Calculations used an absorbance coefficient of $43.6 \mathrm{M}^{-1} \mathrm{~cm}^{-1}$ at $240 \mathrm{~nm}$ (Pilarska et al. 2016). The assay was performed in six replicates for each treatment.

\section{Determination of endogenous hydrogen peroxide level}

The endogenous $\mathrm{H}_{2} \mathrm{O}_{2}$ content was assessed as has been proposed by Barreto et al. (2017). Approximately $150 \mathrm{mg}$ of collected leaf tissue was frozen immediately in liquid nitrogen and ground into a fine powder. The powder was directly homogenized with $1 \mathrm{ml}$ of a solution containing $250 \mu \mathrm{l}$ of $0.1 \%$ $(w / v)$ trichloroacetic acid (TCA), $500 \mu \mathrm{l}$ of $1 \mathrm{M} \mathrm{KI}$ and $250 \mu \mathrm{l}$ of $10 \mathrm{mM}$ potassium phosphate buffer $(\mathrm{pH} 7.0)$ for $10 \mathrm{~min}$, $4{ }^{\circ} \mathrm{C}$ in darkness. The samples were centrifuged at $12,000 \times g$ for $15 \mathrm{~min}, 4^{\circ} \mathrm{C} .200 \mu \mathrm{l}$ of each supernatant was transferred to a new tube and left to incubate without light access at RT for $20 \mathrm{~min}$. Then samples were diluted 10-fold with distilled water and absorbance was measured at $350 \mathrm{~nm}$. For quantification, a calibration curve was obtained using $\mathrm{H}_{2} \mathrm{O}_{2}$ standard solutions prepared in $0.1 \%$ TCA. Data were calculated as $\mu$ moles per gram dry weight $\left(\mu \mathrm{mol} \mathrm{g}{ }^{-1} \mathrm{DW}\right)$. The assay was performed in six replicates for each treatment.

\section{Measurements of leaf lipid peroxidation}

The level of oxidative damage to membranes under drought was estimated indirectly with an assessment of 
byproducts of lipid peroxidation reacted with thiobarbituric acid (TBA) and among them malondialdehyde (MDA) content. The assay was in accordance with the procedure of $\mathrm{Xu}$ et al. (2008). $100 \mathrm{mg}$ of leaf powder was homogenized in $1 \mathrm{ml}$ of $10 \%(\mathrm{w} / \mathrm{v})$ TCA and centrifuged at $10,000 \times \mathrm{g}$ for $15 \mathrm{~min} .1 \mathrm{ml}$ of supernatant was mixed with $1 \mathrm{ml}$ of $0.6 \%(\mathrm{w} / \mathrm{v}) \mathrm{TBA}$, heated at $95{ }^{\circ} \mathrm{C}$ for $30 \mathrm{~min}$ and then quickly cooled down on the ice to RT. After centrifugation at $10,000 \times \mathrm{g}$ for $10 \mathrm{~min}$, the absorbance (A) of the 10 -fold diluted supernatants was measured at $532 \mathrm{~nm}$ and values corresponding to non-specific absorption at $450 \mathrm{~nm}$ and a correction factor for non-specific turbidity at $600 \mathrm{~nm}$. The MDA concentration determined on a fresh weight basis was calculated according to Ying et al. (2015) with the following formula:

$\operatorname{MDA}(\mu \mathrm{mol} \mathrm{g}-1 \mathrm{FW})=6.45 \times\left(\mathrm{A}_{532}-\mathrm{A}_{600}\right)-0.56 \times \mathrm{A}_{450}$

Then data were calculated as $\mu$ moles per gram dry weight $\left(\mu \mathrm{mol} \mathrm{g}{ }^{-1} \mathrm{DW}\right)$. The assay was performed in six replicates for each treatment.

\section{Statistical analysis}

The normal distribution of variables was verified with Shapiro-Wilk's test and the equality of variances was evaluated using Levene's test. The one-way ANOVA and post-hoc Tukey's HSD test were employed to analyze differences between groups. The data are presented as the mean with standard deviation $( \pm \mathrm{SD})$. Statistical significance was determined at the $\alpha=0.05$ level. Statistical analyses were performed using STATISTICA 12.0 statistical software (StatSoft Inc., Oklahoma, USA).

\section{Results}

\section{The effect of soil water availability on leaf relative water content}

The SVWC in the CT treatment was maintained at approximately $26 \%$ throughout the experiment, corresponding to soil water content at $80 \%$ of FC, while in all dehydrated plants was markedly decreased to approximately $12-15 \%$ SVWC (37-46\% of FC) on the last day of water deprivation, suggesting that the water deficiency in the samples was the same (Table 1). The leaf relative water content decreased under drought period (Table 1) more than $70 \%$ in the non-sprayed plants (D) compared to CT while in ABA-, $\mathrm{H}_{2} \mathrm{O}_{2}$ - and Put-treated plants, was reduced by 55 , 66 and $53 \%$, respectively.

\section{Accumulation of proline in response to drought}

Drought significantly induced accumulation of free proline as we noted nearly 1.7-times higher accumulation of this osmoprotectant in D plants compared to CT (Table 1). Among applied regulators only the Put significantly enhanced further Pro accumulation under drought to the nearly 2.5times higher level than in CT. Neither the ABA nor $\mathrm{H}_{2} \mathrm{O}_{2}$ influenced the Pro level in the way similar to Put. Consequently, in the ABA treatment, the Pro level was statistically indistinguishable from $\mathrm{D}$ samples or its accumulation was even lower with $\mathrm{H}_{2} \mathrm{O}_{2}$ treatment.

\section{Photosynthetic pigments accumulation in response to dehydration}

In CT plants the Chl $a+b$ content was kept at $15.44 \mathrm{mg} \mathrm{g}^{-1}$ DW and fell about $76 \%$ in response to drought (Table 1). After the application of ABA and Put $\mathrm{Chl} a+b$ declined by 70 and $63 \%$, respectively compared to the $\mathrm{CT} . \mathrm{H}_{2} \mathrm{O}_{2}$-treated plants showed about $80 \%$ decrease $\mathrm{Chl} a+b$ level as compared with the $\mathrm{CT}$ and $18 \%$ reduction as compared with the $\mathrm{D}$, respectively. Although the analyzed plants showed different $\mathrm{Chl} a+$ $b$ content, the chlorophyll $a / b$ ratio remained unaffected. After foliar application of ABA and Put chlorophyll stability index decreased by 70 and $63 \%$, respectively. The strongest decrease -80 and $76 \%$ was recorded for $\mathrm{H}_{2} \mathrm{O}_{2}$ and $\mathrm{D}$ samples, respectively. Carotenoid content also decreased by $72 \%$ in $\mathrm{D}$ and by 68,77 and $59 \%$ with $\mathrm{ABA}, \mathrm{H}_{2} \mathrm{O}_{2}$ and Put treatment, respectively.

\section{The effects of drought and growth regulators application on the photosynthetic efficiency of PSII}

The maximum quantum efficiency of PSII was practically unaltered under drought, except for $\mathrm{H}_{2} \mathrm{O}_{2}$ application resulting in slightly decreased Fv/fm (Fig. 1a). The analyzed distribution of absorbed energy showed, however, that drought decreased $\Phi$ PSII (Fig. 1b) by approximately $10 \%$ with D and $\mathrm{H}_{2} \mathrm{O}_{2}$ and by $5 \%$ with Put. At the same time, the ABA application allowed to maintain the control-like value of $\Phi$ PSII. Despite the chlorophyll-loss and membrane damage the photosystems maintained in intact chloroplast thylakoids were still active. Such findings have been proved with the analyzed electron transport rate of PSII (Fig. 1d). Water-stress inhibited ETR $_{\text {II }}$ by 17,18 and $7 \%$ in $\mathrm{D}, \mathrm{H}_{2} \mathrm{O}_{2}$ and Put samples, respectively. For the ABA-sprayed plants, the unaltered ETR $_{\text {II }}$ value was noted. Estimated $\mathrm{R}_{\mathrm{Fd}}$ was markedly decreased under drought (Fig. 1c) to 70, 81, 62 and $72 \%$ of $\mathrm{CT}$ value in $\mathrm{D}$, ABA, $\mathrm{H}_{2} \mathrm{O}_{2}$ and Put treatment, respectively. In contrast to $\Phi$ PSII or ETR $\mathrm{II}_{\mathrm{II}}, \mathrm{R}_{\mathrm{Fd}}$ measurement was carried out with higher photon densities saturating the photosynthetic quantum 
Table 1 Soil volumetric water contents (SVWC); leaf relative water content (RWC); chlorophyll $a, b$ : content (Chl $a+b)$, ratio (Chl $a / b)$ and stability index (CSI); carotenoids (pool) and proline level of barley leaves under non-limiting soil water condition and drought

\begin{tabular}{llllllll}
\hline Treatments & SVWC $(\% \mathrm{v} / \mathrm{v})$ & RWC $(\%)$ & $\mathrm{Chl} a+b\left(\mathrm{mg} \mathrm{g}^{-1} \mathrm{DW}\right)$ & $\mathrm{Chl} a / b$ & CSI $(\%)$ & carotenoids $\left(\mathrm{mg} \mathrm{g}^{-1} \mathrm{DW}\right)$ & $\mathrm{proline}\left(\mu \mathrm{mol} \mathrm{g}^{-1} \mathrm{DW}\right)$ \\
\hline $\mathrm{CT}$ & $26.3 \pm 1.22^{\mathrm{a}}$ & $85.7 \pm 3.59^{\mathrm{a}}$ & $15.44 \pm 0.72^{\mathrm{a}}$ & $3.89 \pm 0.02^{\mathrm{a}}$ & $97.5 \pm 4.73^{\mathrm{a}}$ & $2.62 \pm 0.18^{\mathrm{a}}$ & $9.12 \pm 1.98^{\mathrm{d}}$ \\
$\mathrm{D}$ & $12.5 \pm 2.36^{\mathrm{b}}$ & $25.1 \pm 1.53^{\mathrm{c}}$ & $3.77 \pm 0.05^{\mathrm{d}}$ & $3.77 \pm 0.31^{\mathrm{a}}$ & $23.7 \pm 0.30^{\mathrm{d}}$ & $0.74 \pm 0.10^{\mathrm{d}}$ & $15.83 \pm 1.79^{\mathrm{b}}$ \\
$\mathrm{D}+\mathrm{ABA}$ & $14.5 \pm 2.35^{\mathrm{b}}$ & $38.3 \pm 1.15^{\mathrm{b}}$ & $4.66 \pm 0.13^{\mathrm{c}}$ & $3.81 \pm 0.19^{\mathrm{a}}$ & $29.6 \pm 0.97^{\mathrm{c}}$ & $0.85 \pm 0.04^{\mathrm{c}}$ & $17.16 \pm 2.02^{\mathrm{b}}$ \\
$\mathrm{D}+\mathrm{H}_{2} \mathrm{O}_{2}$ & $11.9 \pm 3.00^{\mathrm{b}}$ & $28.9 \pm 1.06^{\mathrm{c}}$ & $3.10 \pm 0.15^{\mathrm{e}}$ & $3.52 \pm 0.73^{\mathrm{a}}$ & $19.6 \pm 1.10^{\mathrm{e}}$ & $0.59 \pm 0.04^{\mathrm{e}}$ & $13.26 \pm 1.81^{\mathrm{c}}$ \\
$\mathrm{D}+\mathrm{Put}$ & $11.7 \pm 2.21^{\mathrm{b}}$ & $40.4 \pm 4.00^{\mathrm{b}}$ & $5.67 \pm 0.09^{\mathrm{b}}$ & $3.33 \pm 0.49^{\mathrm{a}}$ & $36.0 \pm 0.71^{\mathrm{b}}$ & $1.08 \pm 0.05^{\mathrm{b}}$ & $22.23 \pm 2.20^{\mathrm{a}}$ \\
\hline
\end{tabular}

Data are shown as means $\pm \mathrm{SD}(n=10)$. The parameters were measured on the third fully expanded leaf. Different superscript letters in the same column indicate significant differences according to Tukey's HSD test $(\alpha=0.05)$. CT states for the control plants with maintained irrigation. The rest of the plants were exposed to 7-days dehydration without (D) or with foliar application of $100 \mu \mathrm{M}$ abscisic acid (D+ABA), $5 \mathrm{mM}$ hydrogen peroxide $\left(\mathrm{D}+\mathrm{H}_{2} \mathrm{O}_{2}\right)$ and $100 \mu \mathrm{M}$ putrescine (D + Put). DW - dry weight. Data present values of the last day of the experiment

conversion of nearly all leaf chloroplasts, thereby exposing the actual effects of drought on $\mathrm{CO}_{2}$ assimilation.

\section{Drought-induced electron transfer limitation and energy quenching}

Drought stress increased $1-\mathrm{qP}$ significantly as it was 2-, 1.46-, 2.24- and 1.91-fold higher for D, ABA, $\mathrm{H}_{2} \mathrm{O}_{2}$ and Put treatment, respectively (Fig. 2a). Only the ABA-sprayed plants showed markedly reduced $1-\mathrm{qP}$ under drought and consequently CT-like values of $\mathrm{Fv} / \mathrm{fm}$, $\Phi$ PSII, and $\mathrm{ETR}_{\mathrm{II}}$. A comparison of NPQ (Fig. 2b) or $\Phi$ NPQ (Fig. 2c) with $\Phi N O$
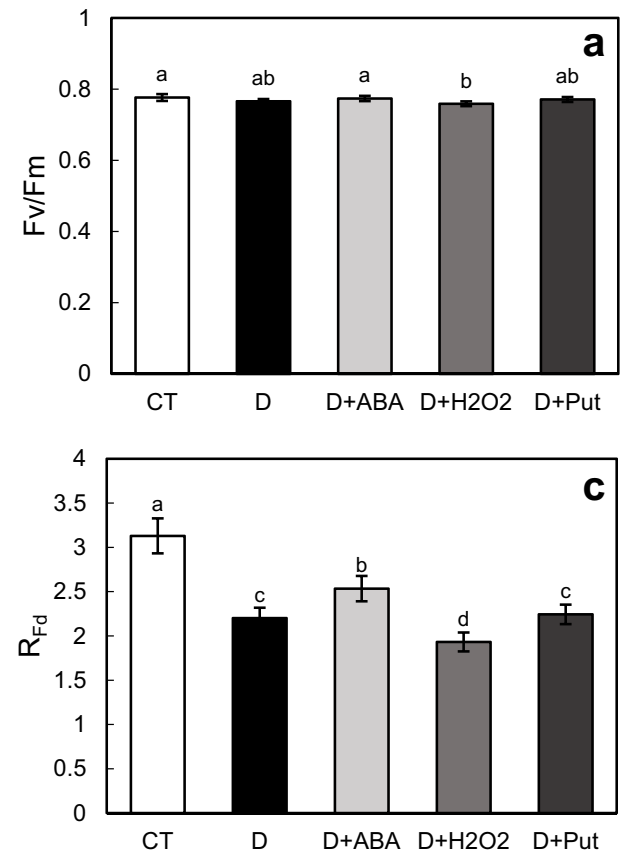

Fig. 1 Effects of exogenous growth regulators application on a) Fv/fm, the maximum quantum yield of PSII, b) $\Phi$ PSII, actual photochemical efficiency of PSII, c) $\mathrm{R}_{\mathrm{Fd}}$, the chlorophyll fluorescence decrease ratio, d) $\mathrm{ETR}_{\mathrm{II}}$, the electron transport rate of PSII in leaves of barley cv. Carina plants. The parameters were measured on the third fully expanded leaf on the last day of the experiment. Data are shown as values (Fig. 2d) clearly showed that under drought nonphotochemical energy dissipation was realized predominantly in a passive manner. Analyzed distribution of absorbed energy showed that water limitation decreased the effectiveness of safety energy dissipation. D plants presented nearly $12 \%$ lower $\Phi$ NPQ and 29\% higher $\Phi$ NO than CT, while ABA- and Put-sprayed plants showed 45 and $6 \%$ higher $\Phi$ NPQ value than $\mathrm{CT}$, and 65 and $21 \%$ increased $\Phi \mathrm{NPQ}$ compared to D plants, respectively. At the same time, $\mathrm{H}_{2} \mathrm{O}_{2}$ application downregulated $\Phi$ NPQ by approximately 23 and $13 \%$ compared to $\mathrm{CT}$ and D, respectively. Analyzed $\Phi \mathrm{NO}$ showed that only $\mathrm{ABA}$ application allowed reducing this parameter,
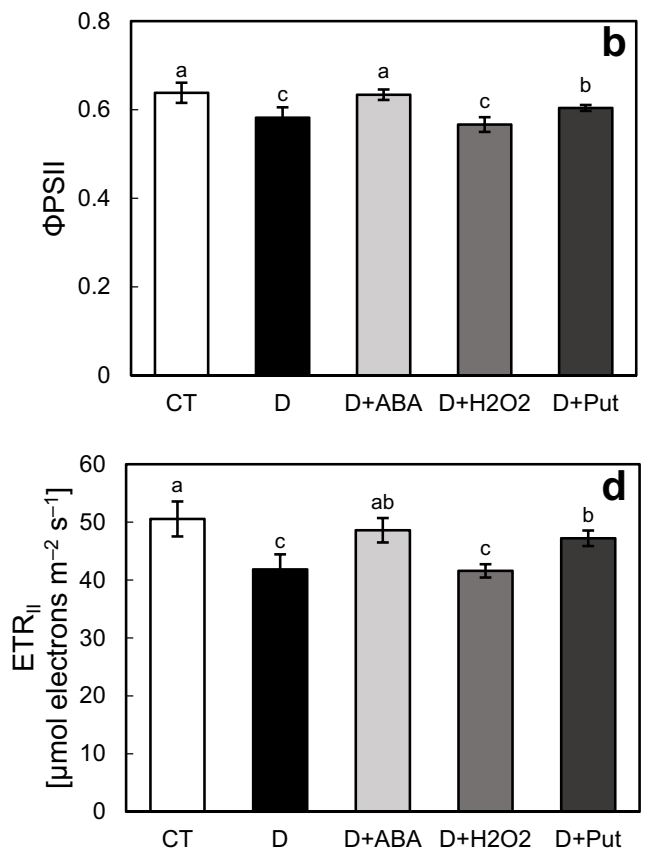

means $\pm \mathrm{SD}(n=6)$. Different letters indicate significant differences according to Tukey's HSD test $(\alpha=0.05)$. CT states for control plants with maintained irrigation. The rest of the plants were exposed to 7-days dehydration without (D) or with foliar application of $100 \mu \mathrm{M}$ abscisic acid (D+ABA), $5 \mathrm{mM}$ hydrogen peroxide $\left(\mathrm{D}+\mathrm{H}_{2} \mathrm{O}_{2}\right)$ and $100 \mu \mathrm{M}$ putrescine $(\mathrm{D}+\mathrm{Put})$ 

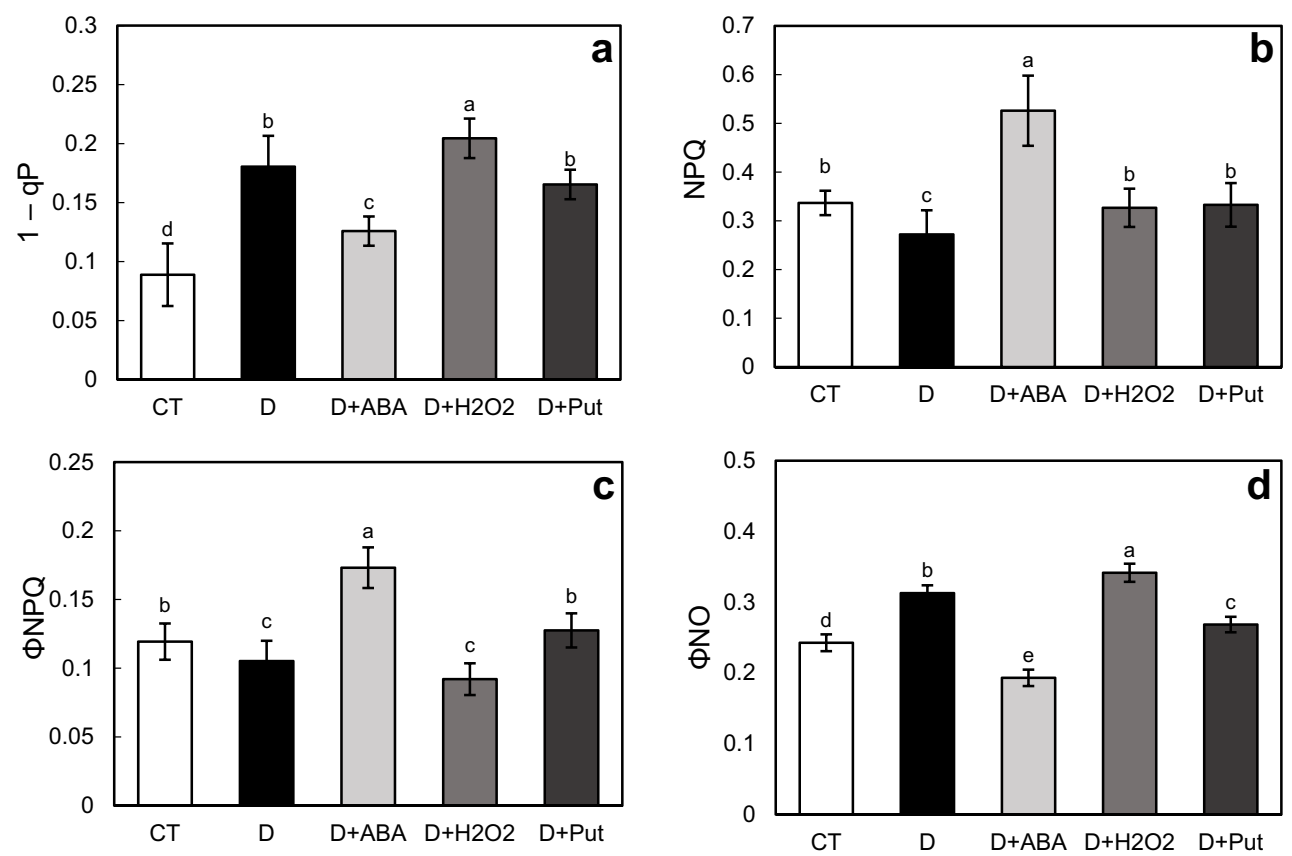

Fig. 2 Effects of exogenous growth regulators application on a) $1-\mathrm{qP}$, excitation pressure on PSII, b) NPQ, non-photochemical quenching, $\mathbf{c}$ ) $\Phi N P Q$, quantum yield of regulated energy dissipation in PSII, d) $\Phi$ NO, quantum yield of non-regulated energy dissipation in PSII in leaves of barley cv. Carina plants. The parameters were measured on the third fully expanded leaf on the last day of the experiment. Data are shown as means

$\pm \mathrm{SD}(n=6)$. Different letters indicate significant differences according to Tukey's HSD test $(\alpha=0.05)$. CT states for control plants with maintained irrigation. The rest of the plants were exposed to 7-days dehydration without (D) or with foliar application of $100 \mu \mathrm{M}$ abscisic acid (D + ABA), $5 \mathrm{mM}$ hydrogen peroxide $\left(\mathrm{D}+\mathrm{H}_{2} \mathrm{O}_{2}\right)$ and $100 \mu \mathrm{M}$ putrescine (D+Put)

presumably as a result of substantially increased $\Phi N P Q$. Increased energy dissipation by the heat of ABA-sprayed samples was also documented with NPQ, as it reached 56\% higher level than in CT. $\mathrm{H}_{2} \mathrm{O}_{2^{-}}$and Put-sprayed plants preserved CT-like NPQ levels, while a significant decrease of NPQ was observed in D samples.

\section{The effects of drought and growth regulators application on the leaf gas-exchange}

Compared with the CT, 7 days of water shortage in $\mathrm{D}$ and $\mathrm{D}+$ $\mathrm{H}_{2} \mathrm{O}_{2}$ plants decreased $P_{\mathrm{n}}$ by 64 and $75 \%$, respectively (Fig. 3a). Application of $100 \mu \mathrm{M}$ Put did not improve the assimilation rate measured on the last day of drought as well. In contrast, exogenously applied ABA increased $P_{\mathrm{n}}$ by over $50 \%$ compared with the D sample. The influence of applied plant growth regulators (PGRs) has been also monitored shortly after application. We noted that all applied PGRs decreased the $P_{\mathrm{n}}$ rate after application by 28,15 and $19 \%$ with ABA, $\mathrm{H}_{2} \mathrm{O}_{2}$ and Put, respectively. The decreased $\mathrm{CO}_{2}$ assimilation rates resulted from the reduced stomatal conductance (Fig. 3b), however, the magnitude of the parameters decrease was not correlated as documented for the D + ABA sample. ABA has been the most effective in rapid stomatal closure and decreased $g_{\mathrm{s}}$ by nearly $70 \%$ shortly after treatment (Day 1 ). At the same time, for the $\mathrm{D}, \mathrm{H}_{2} \mathrm{O}_{2}$ - and Put-treated plants approximately 5,13 and $31 \%$ lower $g_{\mathrm{s}}$ were noted, compared to CT

(Fig. 3b, Day 1). Throughout the experiment, decreasing RWC of leaves progressively reduced stomatal conductance (Fig. 3b, Day 4), slowing $\mathrm{CO}_{2}$ assimilation (Fig. 3a, Day 4). Consistently, the $g_{s}$ level of ABA-sprayed plants on the fourth day was the lowest, but the assimilation rate of the $\mathrm{ABA}$ sample remained quite stable. On the last day of drought leaf dehydration markedly reduced stomatal conductance by 67 , 57, 76 and $70 \%$ for D, ABA, $\mathrm{H}_{2} \mathrm{O}_{2}$ and Put treatments, respectively (Fig. 3b). It should be noted, however, that for the ABA-samples $g_{\mathrm{s}}$ on Day 7 was slightly higher than measured on Day 1 or Day 4, due to lack of ABA-application. Thus, the decreased $g_{\mathrm{s}}$ on the last day was predominantly a result of progressive guard cell dehydration rather than the activity of previously applied ABA.

\section{The effects of water shortage and growth regulators application on plant proteins accumulation}

The abundance of the Rubisco LSU protein was decreased by $48 \%$ under drought (Fig. 3c). Exogenous application of ABA alleviated this adverse effect and plants maintained almost $90 \%$ of the CT level of the enzyme large subunit. In the Putand $\mathrm{H}_{2} \mathrm{O}_{2}$-treated samples accumulation of Rubisco LSU was decreased by 23 and 39\%, respectively.

Drought decreased total Rubisco activase $\left(\mathrm{RCA}_{\text {total }}\right)$ accumulation by 15,6 and $24 \%$ with D, Put and $\mathrm{H}_{2} \mathrm{O}_{2}$-sample, respectively. However, an exception to this were plants- 

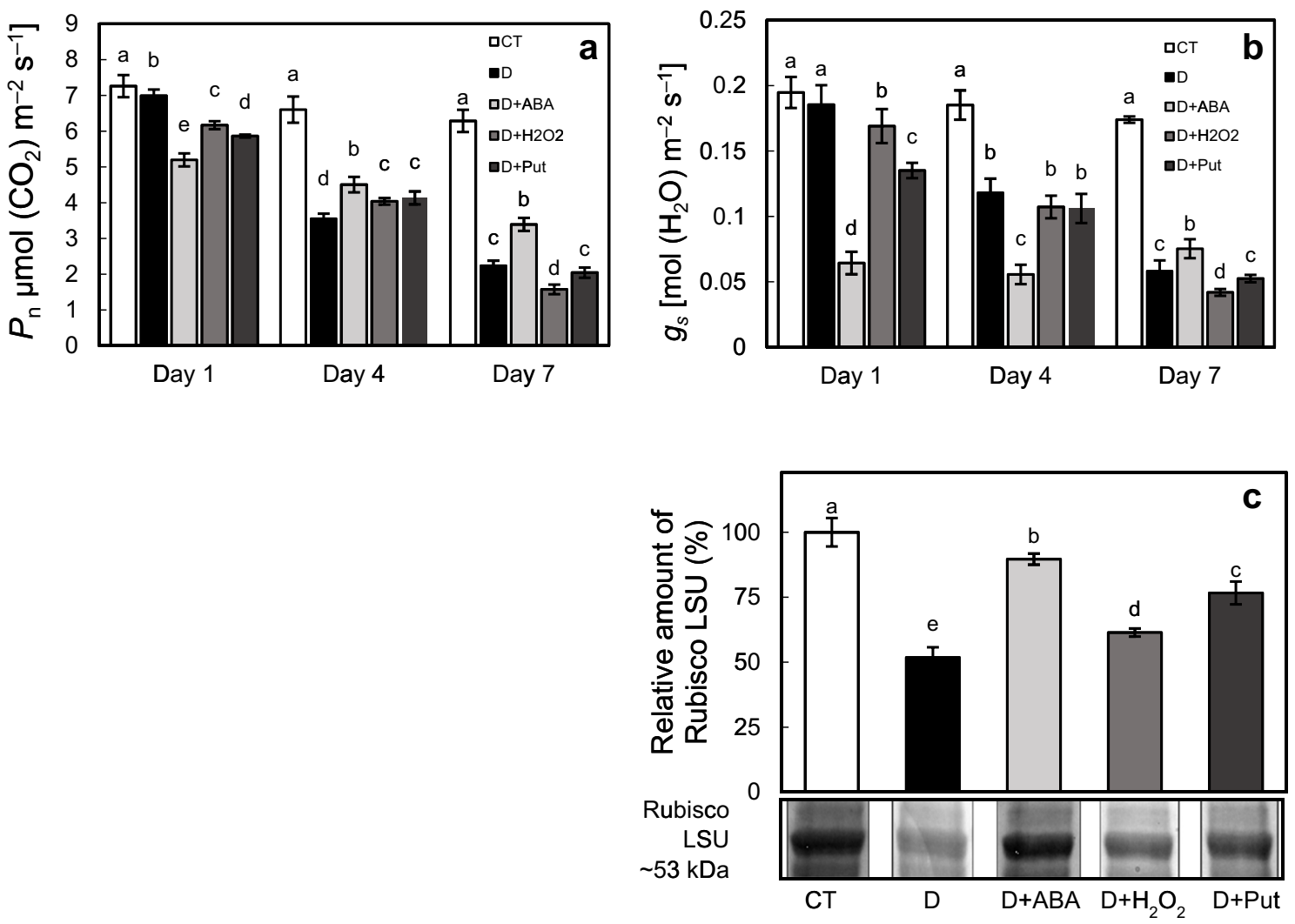

Fig. 3 Effects of exogenous growth regulators application on a) $P_{\mathrm{n}}$, net photosynthetic rate and b) $g_{\mathrm{s}}$, stomatal conductance measurements on the first and fourth day, determined $4 \mathrm{~h}$ after water/solution application or on the last day of the experiment (Day 7), c) Rubisco large subunit (LSU) relative amount (\%), beneath the LSU protein bands $(53 \mathrm{kDa})$ of $20 \mu \mathrm{g}$ protein resolved in a $10 \%$ TGX polyacrylamide gel and visualized with Coomassie Stain. The relative amounts of Rubisco LSU were normalized to CT. The parameters were measured on the third fully expanded leaf on the first, fourth and seventh $(\mathbf{a}, \mathbf{b})$ or the last (seventh) day of experiment

sprayed with ABA, presenting approximately $6 \%$ higher protein level than the CT group (Figs. 4a, b). We did not analyze the differences in the accumulation of particular RCA isoform separately. It should be noted, however, that the level of $\beta$ isoform has been significantly higher than $\alpha$ in all the groups tested (Fig. 4a). The accumulation of PsbO protein of the OEC complex also decreased by an average of $10 \%$ in D, Put- and ABA-sprayed samples and by $17 \%$ in plants sprayed with $\mathrm{H}_{2} \mathrm{O}_{2}$ (Figs. 4a, c).

As protein samples for PGRL1 were prepared under non-reducing conditions and resolved with gradient gel, two distinct signals: 24 and $29 \mathrm{kDa}$ for PGRL1 were noted (Fig. 4a), corresponding to oxidized (PGRL1 $1_{\text {ox }}$ ) and reduced (PGRL1 $1_{\text {red }}$ ) PGRL1 monomers, respectively. No additional signal for PGRL1-PGR5 heterodimers was indicated (Fig. 4a). The ABA-sprayed plants showed 2.5times higher PGRL1 $1_{\text {total }}$ protein level compared to CT, and nearly 4-times higher than non-sprayed plants exposed to drought (D) (Fig. 4d). A comparison of PGRL1 $1_{\text {total }}$ protein accumulation between $\mathrm{D}$ and $\mathrm{H}_{2} \mathrm{O}_{2}$-sprayed plants,

(c). Data are shown as means $\pm \mathrm{SD}(n=10$ for $\mathbf{a}, \mathbf{b}$ or $n=4$ for $\mathbf{c})$. Different letters indicate significant differences according to Tukey's HSD test $(\alpha=0.05)$. In the case of Fig. $\mathbf{a}$ and $\mathbf{b}$ different letters indicate significant differences among means of the same day. CT states for control plants with maintained irrigation. The rest of the plants were exposed to 7-days dehydration without (D) or with foliar application of $100 \mu \mathrm{M}$ abscisic acid (D+ABA), $5 \mathrm{mM}$ hydrogen peroxide $\left(\mathrm{D}+\mathrm{H}_{2} \mathrm{O}_{2}\right)$ and $100 \mu \mathrm{M}$ putrescine $(\mathrm{D}+$ Put). DW - dry weight

clearly demonstrated that the negative effect of waterstress on PGRL $1_{\text {total }}$ protein level was further aggravated with $\mathrm{H}_{2} \mathrm{O}_{2}$ application. Moreover, the fraction of PGRL1 monomers in the reduced state increased from approximately $60 \%$ in the $\mathrm{CT}$ to $70 \%$ in $\mathrm{D}$ and $\mathrm{H}_{2} \mathrm{O}_{2}$-sprayed plants. The lowest PGRL1 $1_{\text {red }} / \mathrm{PGRL} 1_{\text {ox }}$ ratio was noted for ABA-sprayed plants (Fig. 4f). At the same time, $\mathrm{NdhS}$ protein was significantly increased in $\mathrm{D}$ and $\mathrm{H}_{2} \mathrm{O}_{2}$ plants, as 3- and 2-times higher levels of NDH complex subunit $\mathrm{S}$, compared to $\mathrm{CT}$, were noted in both treatments, respectively (Fig. 4e). This indicates that accumulation of NdhS under drought was only partially suppressed by exogenous $\mathrm{H}_{2} \mathrm{O}_{2}$ since neither ABA- nor Put-sprayed samples showed any alteration in $\mathrm{NdhS}$ content under drought compared to $\mathrm{CT}$.

\section{The activity of SOD and CAT in response to drought}

Drought induced over $20 \%$ decrease of SOD activity in the case of D sample and 6 and $2 \%$ with ABA and Put 

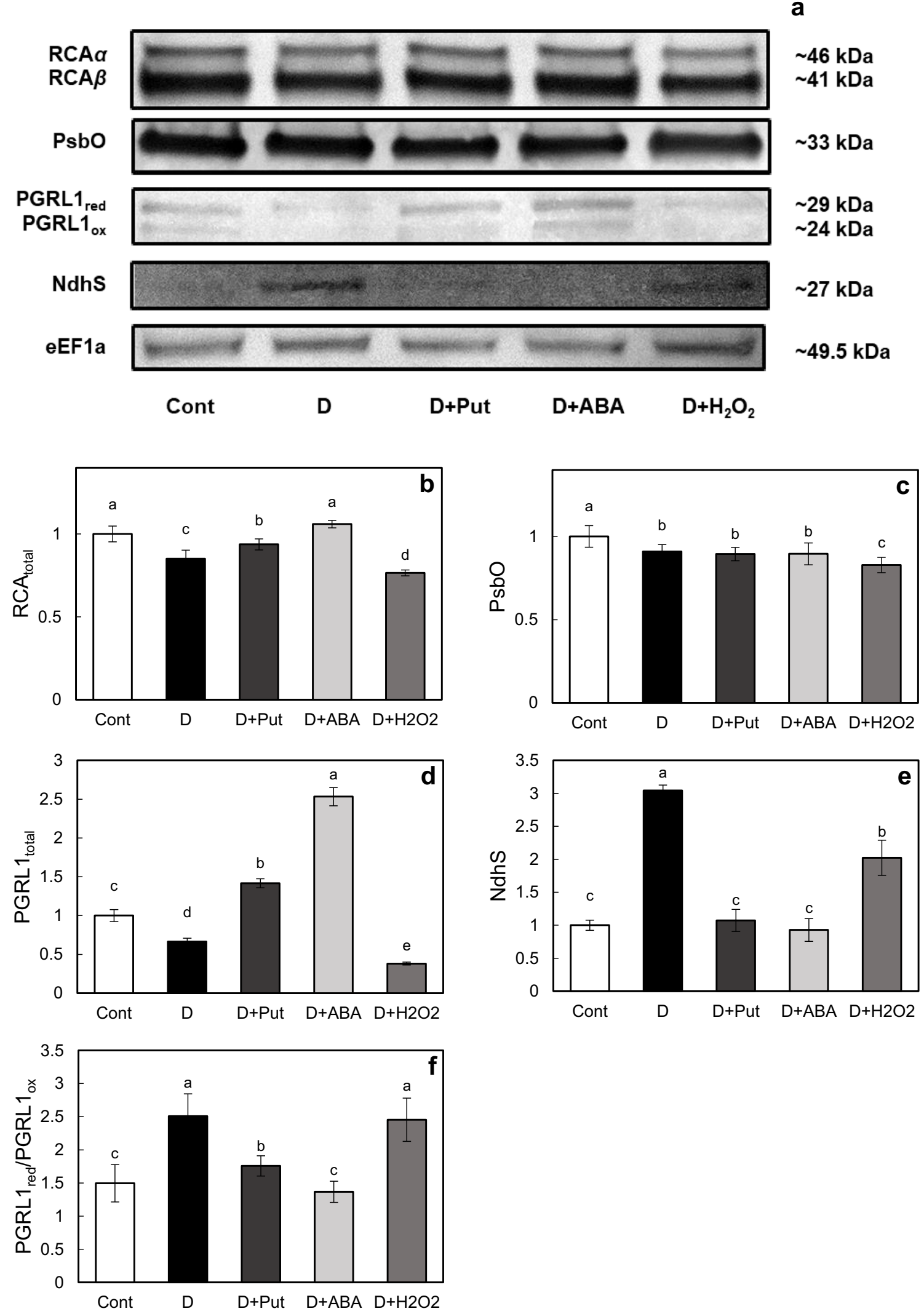

application, respectively (Fig. 5c). Besides, in relation to 29\%. Thus, all applied PGRs mitigated the droughtthe $\mathrm{CT}$, the $\mathrm{H}_{2} \mathrm{O}_{2}$ treatment enhanced the SOD activity by triggered down-regulation of the SOD activity. Analyzed 
Fig. 4 a) Western Blot analyses of Rubisco activase (RCA) ( $\alpha$ - and $\beta$ isoform), PsbO, PGRL1 [red(uced) and ox(idized) monomer] and NdhS protein (eEF1a is the loading control). Immunoblotting was done with barley leaf extracts from the third fully expanded leaf on the last day of the experiment. For RCA, PsbO and eEF1a $5 \mu \mathrm{g}$, and for PGRL1 and NdhS $25 \mu \mathrm{g}$ protein per lane were loaded, resolved in 4-20\% TGX polyacrylamide gels, transferred to nitrocellulose membrane and visualized with DAB (a). Densitometric analysis and quantification were conducted using ImageJ v.1.52 (b, c, d, e, f). b) RCA signal was estimated from both $\alpha$ - and $\beta$-isoform bands visualized on the membrane, as an overall RCA content $\left(\mathrm{RCA}_{\text {total }}\right)$. d) For PGRL1 $1_{\text {total }}$ quantification both redox state forms were combined. f) The ratio of PGRL $1_{\text {red }} / P G R L 1_{\text {ox }}$ indicates the ratio of reduced $(29 \mathrm{kDa})$ to oxidized $(24 \mathrm{kDa})$ form of PGRL1 protein. Different letters indicate significant differences according to Tukey's HSD test $(\alpha=0.05)$. The values of $\mathbf{b}, \mathbf{c}, \mathbf{d}, \mathbf{e}$ are normalized to CT. Data are shown as means $\pm \mathrm{SD}(n=3$ for $\mathbf{b}, \mathbf{c}, \mathbf{d}, \mathbf{e}, \mathbf{f})$. CT states for control plants with maintained irrigation. The rest of the plants were exposed to 7-days dehydration without (D) or with foliar application of $100 \mu \mathrm{M}$ putrescine $(\mathrm{D}+\mathrm{Put}), 100 \mu \mathrm{M}$ abscisic acid $(\mathrm{D}+\mathrm{ABA})$ and $5 \mathrm{mM}$ hydrogen peroxide $\left(\mathrm{D}+\mathrm{H}_{2} \mathrm{O}_{2}\right)$

CAT activity presented an opposite trend to SOD as drought increased enzyme activity by approximately 69 , 103, 76 and $119 \%$ in D, D + ABA, D $+\mathrm{H}_{2} \mathrm{O}_{2}$, and D + Put samples, respectively (Fig. 5d). It should be noted, however, that while $\mathrm{H}_{2} \mathrm{O}_{2}$ application effectively induced SOD activity it was less efficient in mediating CAT activation. No significant difference between $\mathrm{D}$ and $\mathrm{D}+\mathrm{H}_{2} \mathrm{O}_{2}$ samples was observed in enzyme activity, despite the increased endogenous level of $\mathrm{H}_{2} \mathrm{O}_{2}$ in the latter one (Figs. 5b, d).
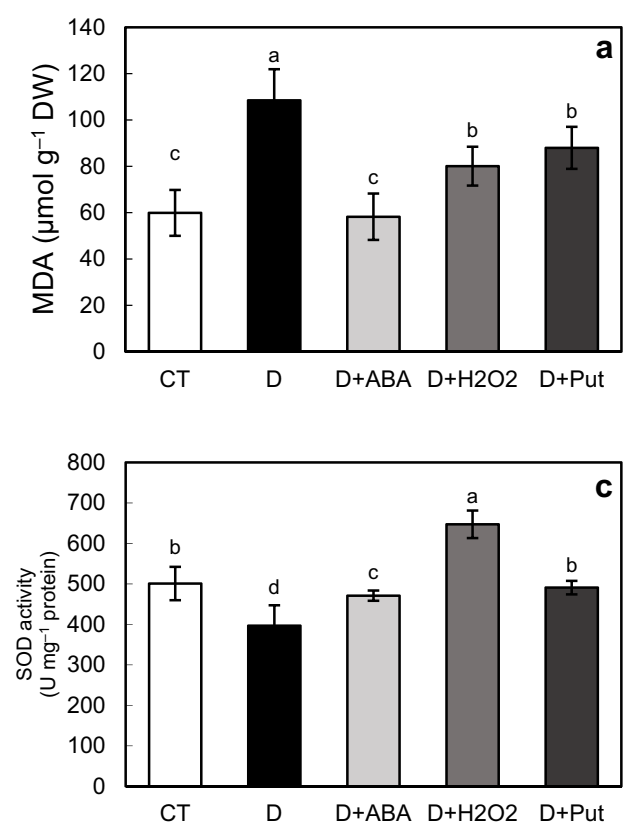

Fig. 5 Effects of exogenous growth regulators application on a) MDA, malondialdehyde accumulation, b) $\mathrm{H}_{2} \mathrm{O}_{2}$, endogenous hydrogen peroxide level, c) SOD, superoxide dismutase and d) CAT, catalase activity in leaves of barley plants. The parameters were measured on the third fully expanded leaf on the last day of the experiment. Data are shown as means $\pm \mathrm{SD}(n=6)$. Different letters indicate significant
The effect of growth regulators on endogenous $\mathrm{H}_{2} \mathrm{O}_{2}$ accumulation and lipid peroxidation rate under drought

Leaves of the CT plants accumulated approximately $2.28 \mu \mathrm{mol}$ of $\mathrm{H}_{2} \mathrm{O}_{2}$ per gram DW (Fig. 5b) and dehydration increased its accumulation in all the samples tested. Yet, there was a clear correlation between the used PGR and $\mathrm{H}_{2} \mathrm{O}_{2}$ levels. In the plants exposed to drought and not sprayed nearly a 1.5-fold increase of $\mathrm{H}_{2} \mathrm{O}_{2}$ accumulation was estimated. At the same time, the application of $\mathrm{ABA}$, exogenous $\mathrm{H}_{2} \mathrm{O}_{2}$ and Put induced 1.8-fold, 2-fold and 1.6-fold $\mathrm{H}_{2} \mathrm{O}_{2}$ increase, respectively. Comparison between $\mathrm{D}$ and $\mathrm{ABA}$ samples allows distinguishing between drought-itself and additional ABArelated induction of $\mathrm{H}_{2} \mathrm{O}_{2}$ accumulation, presumably resulted from hormone-induced signaling pathways. Moreover, the highest $\mathrm{H}_{2} \mathrm{O}_{2}$ level was noted for the $\mathrm{H}_{2} \mathrm{O}_{2}$-treated plants along with unchanged CAT activity compared to the $\mathrm{D}$ sample. Thus it was rather the increased SOD activity (Fig. 5c) that enhanced the endogenous $\mathrm{H}_{2} \mathrm{O}_{2}$ level, than the accumulation of the applied PGR as $\mathrm{H}_{2} \mathrm{O}_{2}$ is a short-lived molecule and its last application was done three days before analyses. Put samples showed a $10 \%$ higher accumulation of $\mathrm{H}_{2} \mathrm{O}_{2}$ compared to $\mathrm{D}$, presumably related to increased amine catabolism with oxidases.

The drought-induced ROS accumulation enhanced the lipid peroxidation rate estimated by malondialdehyde content
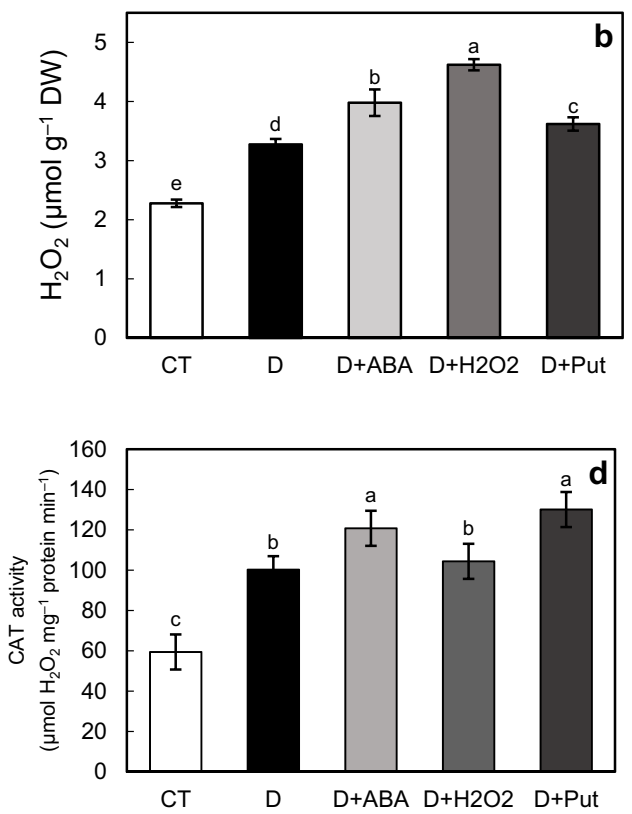

differences according to Tukey's HSD test $(\alpha=0.05)$. CT states for control plants with maintained irrigation. The rest of the plants were exposed to 7-days dehydration without (D) or with foliar application of $100 \mu \mathrm{M}$ abscisic acid (D+ ABA), $5 \mathrm{mM}$ hydrogen peroxide $\left(\mathrm{D}+\mathrm{H}_{2} \mathrm{O}_{2}\right)$ and $100 \mu \mathrm{M}$ putrescine (D + Put). DW - dry weight 
(Fig. 5a). MDA accumulation corresponds to the membrane oxidative damage, thus it increased more than 1.8-fold under drought (D). $\mathrm{H}_{2} \mathrm{O}_{2}$ and Put alleviated lipid peroxidation as despite drought only 1.34 - and 1.47-fold higher MDA content was noted for these treatments compared to $\mathrm{CT}$, respectively. ABA application was the most effective in reducing membrane injuries noticed with over $46 \%$ lower MDA accumulation compared to the non-sprayed D plants. It should be noted that the MDA level in ABA-sprayed samples under drought was as low as in the well-watered CT plants.

\section{Discussion}

Plants during growth are subjected to periodic water-stress episodes which impose defense response realized to compensate for drought-related alterations (De Souza et al. 2015). Current research revealed that decreasing soil water content significantly reduced leaf RWC (Table 1). Put and ABA application was the most effective in maintaining the water status of barley leaves under drought. However, only the ABA treatment improved the water status via stomatal conductance regulation since the first day of its application (Fig. 3b). The effect of Put was related rather to increased Pro accumulation (Table 1) acting as an osmolyte for osmotic adjustment under stress (Farooq et al. 2017). Ishibashi et al. (2011) reported that the leaf wilting might be also delayed by $\mathrm{H}_{2} \mathrm{O}_{2}$ spraying but, as shown in Table 1 and Fig. $3 b$, the $\mathrm{H}_{2} \mathrm{O}_{2}$ application did not improve the leaf water retention at all.

Although the water shortage caused significant chlorophylls and carotenoids loss and decreased the CSI, exogenous ABA and Put also improved chlorophyll retention (Table 1). Similarly, Li et al. (2016) showed that ABA mitigates the degradation of photosynthetic pigments under drought. The mechanism of delayed chlorophyll degradation in the case of Put resulted presumably from its influence on thylakoid membranes by stabilizing photosystem complexes as has been shown by Li et al. (2015) and Shu et al. (2015). We also observed that drought-caused pigments decline did not influence $\mathrm{Chl} a / b$ ratio among all analyzed plants, suggesting that the rate of decomposition of the reaction center complexes and the Chl $b$-rich external antennae were similar (Kura-Hotta et al. 1987).

Drought (D) induced a significant decline of $\Phi$ PSII (Fig. 1b), indicating that $\mathrm{ETR}_{\mathrm{II}}$ was reduced in response to drought stress. In contrast, no significant difference between control and stressed plants was observed in Fv/fm value (Fig. 1a), indicating that this parameter might not be a good indicator of short-term plant drought stress (Yao et al. 2018). Analyzed $\mathrm{D}$ and $\mathrm{H}_{2} \mathrm{O}_{2}$ samples presented markedly increased $1-q \mathrm{P}$, whereas $\mathrm{ABA}$ and Put treatment allowed to maintain $\mathrm{Q}_{\mathrm{A}}$ less reduced (Figs. 1d, 2a). The ABA-based protection of the photosynthetic apparatus was also realized by significant activation of NPQ (Figs. 2b, c) and markedly restricted membrane injury (Fig. 5a). The plants sprayed with Put showed NPQ and $\Phi$ NPQ improvement, however significantly less pronounced than has been reported previously by Ioannidis and Kotzabasis (2007). Thus it might be a result of the lower concentration of applied amine and scarce role of putrescine, compared to spermidine or spermine, as a stimulator of nonphotochemical quenching (Ioannidis and Kotzabasis 2007). Put application had beneficial effects on $\Phi$ PSII and ETR ${ }_{I I}$, when compared with $\mathrm{D}$ sample, but decreased $\mathrm{R}_{\mathrm{Fd}}$ and $P_{\mathrm{n}}$ value proved that amine did not improve the actual $\mathrm{CO}_{2}$-assimilation rate. Results documented that the highest value of $\mathrm{R}_{\mathrm{Fd}}$ was maintained by $\mathrm{ABA}$ - and the lowest by $\mathrm{H}_{2} \mathrm{O}_{2}$ sprayed plants (Fig. 1c). Thus, hydrogen peroxide, despite its role in the ABA signaling cascade was not effective to induce drought acclimation as has been proposed by de Sousa et al. (2016) due to the negative adding effect of the $\mathrm{H}_{2} \mathrm{O}_{2}$ solution with the stress on photosynthetic efficiency (Figs. 1c, 2a, 3a and 4b). Moreover, measurement of absorbed energy distribution in PSII showed that $\mathrm{H}_{2} \mathrm{O}_{2}$ treatment enhanced predominantly the fraction of energy passively dissipated in the form of heat and fluorescence (Fig. 2d).

Exposure to drought results in reduced SOD activity (Fig. 5c) and increased CAT activity compared to CT (Fig. 5d). Enhanced activity of CAT did not compensate, however, for increased $\mathrm{H}_{2} \mathrm{O}_{2}$ production in $\mathrm{D}$ sample. At the same time, the $\mathrm{H}_{2} \mathrm{O}_{2}$ application stimulated the leaf SOD activity. In ABAand Put-sprayed samples SOD activity remained little or almost unaffected compared to $\mathrm{CT}$, respectively, while CAT activity has been significantly increased. Moreover, the mentioned earlier close correlation of the ABA signaling pathway and $\mathrm{H}_{2} \mathrm{O}_{2}$ was confirmed by the significantly increased level of $\mathrm{H}_{2} \mathrm{O}_{2}$ in the ABA-treated plants under drought (Fig. 5b). In our study, the $\mathrm{H}_{2} \mathrm{O}_{2}$ application was however even more effective to stimulate $\mathrm{H}_{2} \mathrm{O}_{2}$ accumulation under drought than ABA itself. The previous reports of Terzi et al. (2014) and de Sousa et al. (2016) showed that $\mathrm{H}_{2} \mathrm{O}_{2}$ application induced antioxidant defense lowering its cellular level. Yet, Lu et al. (2013) indicated that plant reaction is related to its drought tolerance and for sensitive cultivar, such as analyzed Carina, an increased level of $\mathrm{H}_{2} \mathrm{O}_{2}$ after treatment might be noted. In the case of the Put application, sprayed plants showed a moderate increase of $\mathrm{H}_{2} \mathrm{O}_{2}$ level. Thus, it might be concluded that although Put application enhanced the activity of amine oxidases, the enzyme-drove $\mathrm{H}_{2} \mathrm{O}_{2}$ accumulation was restricted due to concomitant antioxidant properties of Put (Pottosin and Shabala 2014) and induced CAT activity (Fig. 5d).

The most abundant final product of ROS-triggered lipid peroxidation is MDA (Pilarska et al. 2017) and its accumulation under drought was related to the SOD activity and endogenous $\mathrm{H}_{2} \mathrm{O}_{2}$ level as shown within the CT and non-sprayed (D) sample (Figs. 5a-c). However, within plants sprayed with tested PGRs, there was no such obvious tendency for MDA 
accumulation level under drought. The increased rate of membrane peroxidation, therefore, seems to be related to more than one oxidative agent and changes in the integrated antioxidant system. We noted that $\mathrm{H}_{2} \mathrm{O}_{2}$ and Put application lowered MDA accumulation, however only the ABA-treated plants showed significantly restricted peroxidation rate, similar to CT samples (Fig. 5a). Reduced accumulation of MDA content after ABA treatment under drought was similar to those found by Sezgin et al. (2018).

According to Castrillo et al. (2001) severe water stress decreases $P_{\mathrm{n}}$ by both the stomatal closure and direct inhibition of the biochemical reaction. The exogenous ABA induced rapid stomatal closure shortly after treatment (Fig. 3b), similarly to action realized with guard cellautonomously synthesized ABA (Bauer et al. 2013), thus immediately restricting water loss. The rapid decrease of leaf stomatal conductance after the ABA application has been also documented by Wang et al. (2020). In contrast, Put application was significantly less effective in rapid stomatal closure. Despite the enhanced RWC level, the $g_{\mathrm{s}}$ of the Put-treated plants, at the end of the drought, was as low as noted for the non-sprayed plants (Fig. 3b). The effectiveness of foliar ABA pre-treatment is documented by comparison of $P_{\mathrm{n}}$ and $g_{\mathrm{s}}$ values on Day 1 . The latter one has been decreased by ABA application by nearly $70 \%$ (Fig. 3b), whilst the $\mathrm{CO}_{2}$ assimilation rate lowered by $28 \%$ compared to $\mathrm{CT}$ value (Fig. $3 \mathrm{a}$ ). These results indicated that under nonsaturating light conditions, applied for gas exchange measurements, the decreased $\mathrm{CO}_{2}$ influx did not translate directly into damped $\mathrm{CO}_{2}$ assimilation. Brito et al. (2020) also demonstrated that ABA pre-treatment allowed the delay of the negative drought effects on net photosynthesis. Therefore, upon drought stress, an important physiological function of $\mathrm{ABA}$ is to reduce the number of ions in the guard cells to decrease the turgor pressure, which induces stomatal closure enhancing water retention capacity (Dong et al. 2019).

ABA links environmental stress perception with the photosynthetic capacity by repressed expression of nuclear- and chloroplast-encoded genes and subsequently the level of the photosynthetic proteins such as Rubisco (Yamburenko et al. 2013). In contrast to this, in ABA-sprayed plants under drought, only limited downregulation of Rubisco LSU and PsbO protein has been documented (Figs. $3 \mathrm{c}$ and $4 \mathrm{a}-\mathrm{e}$ ). Also Put application seemed to protect these proteins against proteolysis, likely as a result of induced Pro accumulation (Table 1) ( $\mathrm{Li}$ et al. 2015). In the case of $\mathrm{H}_{2} \mathrm{O}_{2}$, the previous proteomic analysis showed, that at least 144 protein expression was altered upon exposure to $\mathrm{H}_{2} \mathrm{O}_{2}$. Among them, Rubisco and RCA were downregulated while PsbO was upregulated (Wan and Liu 2008). Comparison of the first two proteins accumulation under drought in ABA- and $\mathrm{H}_{2} \mathrm{O}_{2}$ sprayed plants showed, however, that increased endogenous
$\mathrm{H}_{2} \mathrm{O}_{2}$ accumulation (Fig. 5b) is not a sufficient factor for decreased Rubisco and RCA level (Figs. $3 c$ and $4 b$ ). The decreased $\mathrm{RCA}_{\text {total }}$ and even more the Rubisco LSU level was concurrent with the change in the analyzed $\mathrm{CO}_{2}$-assimilation rate on the last day of drought (Fig. 3a). However, the magnitude of $P_{\mathrm{n}}$ decrease on the last day of drought in all the groups tested is a clear indication of additional limitations such as $g_{\mathrm{s}}$ and disturbed electron transfer.

Chen et al. (2016) documented that the level of both OEC complex proteins - PsbO and PsbP were kept almost unchanged in response to water deficit stress, which was also confirmed in our study. The disassembly of OEC extrinsic proteins would induce the donor side limitation of PSII. However, we observed rather opposite results. In D and $\mathrm{H}_{2} \mathrm{O}_{2}$-sprayed plants the decreased rate of electron transport from PSII toward PSI (Fig. 1d) and increased excitation pressure of PSII was observed (Fig. 2a), thus the ability of PSII to reduce the $\mathrm{Q}_{\mathrm{A}}$ was not altered (Sperdouli and Moustakas 2012). These results suggest that OEC activity has been maintained in all groups under drought.

Drought stress modifies the expression of genes encoding proteins involved in cyclic electron flow around PSI (Lehtimäki et al. 2010). Along with the PGR5/PGRL1 main pathway of CEF-PSI, also the chloroplast NDH-complex might compensate the ATP/NADPH production ratio (Nikkanen et al. 2019). We found that ABA-sprayed plants under drought presented increased accumulation of PGRL1 protein (Figs. 4a, d) and less reduced acceptor side of PSII (Fig. 2a) compared to D sample. Based on these findings it is proposed that in ABA-sprayed plants efficient electron transfer from PSI with ferredoxin (Fd) to PGR5/PGRL1 and then to cytochrome $b_{6} f\left(\mathrm{cyt} b_{6} f\right)$ through plastoquinone (PQ) was noted (Li et al. 2018). Interestingly, as in the report of Hertle et al. (2013), we were also able to fraction two different PGRL1 monomers - larger $(29 \mathrm{kDa})$ reduced and smaller (24 kDa) oxidized form. The analyzed ratio of PGRL $1_{\text {red }}$ to PGRL1 $_{\text {ox }}$ (Fig. 4f) indicated the water limitation induced higher accumulation of PGRL $1_{\text {red }}$ form, meaning that PSI is presumably also reduced (Hertle et al. 2013). However, the Put- and ABA-sprayed plants maintained a lower ratio of PGRL1 $1_{\text {red }}$ to PGRL1 $1_{\text {ox }}$, close to the value noted with CT. Thus, it is reasonable to state that Put- and even more the ABA-treated samples maintained a higher pool of PGRL $1_{\text {ox }}$ by efficient electron transfer from PGRL $1_{\text {red }}$ to PQ interacting with cyt $b_{6} f$ (Hertle et al. 2013). Consequently, increased transmembrane proton gradient was build up in sprayed plants activating protective energy dissipation by nonphotochemical quenching (NPQ) (Figs. 2b, c).

In the case of $\mathrm{NDH}$, we analyzed $\mathrm{NdhS}$ protein that forms the Fd-binding site of the chloroplast NDH complex (Shikanai 2016). The NdhS increased accumulation noted in $D$ and, to a lesser extent, in $\mathrm{H}_{2} \mathrm{O}_{2}$-treated plants might be related to endogenous $\mathrm{H}_{2} \mathrm{O}_{2}$ level, compared to $\mathrm{CT}$, as $\mathrm{NDH}$ can be 
activated in vivo by $\mathrm{H}_{2} \mathrm{O}_{2}$ (Casano et al. 2001). However, in the case of ABA-sprayed plants, enhanced hydrogen peroxide level did not induce the NdhS accumulation. It might be the fact that CEF is already operating with ABA-activated PGR5/ PGRL1 complex as both CEF routes present compensatory activity (Suorsa 2015). An explanation of NdhS increased level in $\mathrm{D}$ and $\mathrm{H}_{2} \mathrm{O}_{2}$-sprayed plants might be the fact that the NDH complex is activated prior to the onset of plant senescence, as documented by Zapata et al. (2005). The author showed that expression of $n d h$ genes is required for leaf senescence as NDH enhanced the reduction of electron transporters, generation of ROS, higher MDA level, decreased activity of the Calvin cycle and finally induction of leaf programmed cell death (PCD) (Zapata et al. 2005). Indeed, a lot of senescence-associated traits such as chlorophyll-loss, photosynthesis downregulation, electron transporters over-reduction, increased MDA and ROS level, were noted for D and $\mathrm{H}_{2} \mathrm{O}_{2}$-sprayed plants.

\section{Conclusions}

The study demonstrated that foliar application of abscisic acid attenuated the effect of drought in barley through the maintenance of water status and protection of the photosynthetic machinery. ABA pre-treatment was also effective in managing stomatal conductance, preserving $\mathrm{CO}_{2}$ fixation, $\mathrm{SOD}$ and CAT activities, reducing the rate of membrane lipid peroxidation and increased the level of PGRL1 protein. Thus, it seems that the mechanism of ABA action on plant acclimation to drought, besides restriction of water-loss, relies on less reduced quinone pool measured with $1-\mathrm{qP}$ and maintained electron transport from PSII to PSI, protected by NPQ thermal dissipation. A beneficial, but significantly less pronounced acclimation response to drought was observed in plants with putrescine pre-treatment. The hydrogen peroxide treatment has been shown to exacerbate drought stress in many physiological and biochemical aspects.

Supplementary Information The online version contains supplementary material available at https://doi.org/10.2478/s11756-020-00644-2.

Acknowledgments This study was supported by the Polish National Science Center (Grant No. UMO-2014/15/N/NZ9/01378) and the Polish Ministry of Science and Higher Education (Grant No. 612078).

Author contributions ES and MT contributed equally. ES and MT conceived and designed research, performed all experimental analyses and carried out data analysis. Both authors read the final manuscript and approved the submission.

\section{Compliance with ethical standards}

Conflict of interest The authors declare that they have no conflict of interest.
Open Access This article is licensed under a Creative Commons Attribution 4.0 International License, which permits use, sharing, adaptation, distribution and reproduction in any medium or format, as long as you give appropriate credit to the original author(s) and the source, provide a link to the Creative Commons licence, and indicate if changes were made. The images or other third party material in this article are included in the article's Creative Commons licence, unless indicated otherwise in a credit line to the material. If material is not included in the article's Creative Commons licence and your intended use is not permitted by statutory regulation or exceeds the permitted use, you will need to obtain permission directly from the copyright holder. To view a copy of this licence, visit http://creativecommons.org/licenses/by/4.0/.

\section{References}

Aebi H (1984) Catalase in vitro. Methods Enzymol 105:121-126

Alcázar R, Altabella T, Marco F, Bortolotti C, Reymond M, Koncz C, Carrasco P, Tiburcio AF (2010) Polyamines: molecules with regulatory functions in plant abiotic stress tolerance. Planta 231(6): 1237-1249

Alexander RD, Wendelboe-Nelson C, Morris PC (2019) The barley transcription factor HvMYB1 is a positive regulator of drought tolerance. Plant Physiol Biochem 142:246-253

Barreto P, Yassitepe J, Wilson Z, Arruda P (2017) Mitochondrial uncoupling protein 1 overexpression increases yield in Nicotiana tabacum under drought stress by improving source and sink metabolism. Front Plant Sci 8:1836. https://doi.org/10.3389/fpls.2017. 01836

Bauer H, Ache P, Lautner S, Fromm J, Hartung W, Al-Rasheid KA, Sonnewald S, Sonnewald U, Kneitz S, Lachmann N, Mendel RR, Bittner F, Hetherington AM, Hedrich R (2013) The stomatal response to reduced relative humidity requires guard cellautonomous ABA synthesis. Curr Biol 23(1):53-57

Bradford MM (1976) A rapid and sensitive method for the quantitation of microgram quantities of protein utilizing the principle of protein-dye binding. Anal Biochem 72(1-2):248-254

Brito C, Dinis LT, Ferreira H, Moutinho-Pereira J, Correia CM (2020) Foliar pre-treatment with Abscisic acid enhances olive tree drought adaptability. Plants 9(3):341

Cardoso AA, Gori A, Da-Silva CJ, Brunetti C (2020) Abscisic acid biosynthesis and signaling in plants: key targets to improve water use efficiency and drought tolerance. Appl Sci 18:6322

Casano LM, Martın M, Sabater B (2001) Hydrogen peroxide mediates the induction of chloroplastic Ndh complex under photooxidative stress in barley. Plant Physiol 125(3):1450-1458

Castrillo M, Fernandez D, Calcagno AM, Trujillo I, Guenni L (2001) Responses of ribulose-1,5-bisphosphate carboxylase, protein content, and stomatal conductance to water deficit in maize, tomato, and bean. Photosynthetica 39(2):221-226

Chen YE, Liu WJ, Su YQ, Cui JM, Zhang ZW, Yuan M, Zhang HY, Yuan S (2016) Different response of photosystem II to short and long-term drought stress in Arabidopsis thaliana. Physiol Plant 158(2):225-235

Cruz de Carvalho MH (2008) Drought stress and reactive oxygen species: production, scavenging and signaling. Plant Signal Behav 3:156165

Cuevas JC, López-Cobollo R, Alcázar R, Zarza X, Koncz C, Altabella T, Salinas J, Tiburcio AF, Ferrando A (2008) Putrescine is involved in Arabidopsis freezing tolerance and cold acclimation by regulating abscisic acid levels in response to low temperature. Plant Physiol 148(2):1094-1105 
Czarnocka W, Karpiński S (2018) Friend or foe? Reactive oxygen species production, scavenging and signaling in plant response to environmental stresses. Free Radic Biol Med 122:4-20

Dahal K, Martyn GD, Alber NA, Vanlerberghe GC (2017) Coordinated regulation of photosynthetic and respiratory components is necessary to maintain chloroplast energy balance in varied growth conditions. J Exp Bot 68(3):657-671

Daszkowska-Golec A, Szarejko I (2013) Open or close the gate-stomata action under the control of phytohormones in drought stress conditions. Front Plant Sci 4:138

De Sousa DPF, Braga BB, Gondim FA, Gomes-Filho E, Martins K, de Brito POB (2016) Increased drought tolerance in maize plants induced by $\mathrm{H}_{2} \mathrm{O}_{2}$ is closely related to an enhanced enzymatic antioxidant system and higher soluble protein and organic solutes contents. Theor Exp Plant Phys 28(3):297-306

De Souza AP, Cocuron JC, Garcia AC, Alonso AP, Buckeridge MS (2015) Changes in whole-plant metabolism during the grain-filling stage in sorghum grown under elevated $\mathrm{CO}_{2}$ and drought. Plant Physiol 169:1755-1765

Desikan R, Cheung MK, Bright J, Henson D, Hancock JT, Neill SJ (2004) ABA, hydrogen peroxide and nitric oxide signalling in stomatal guard cells. J Exp Bot 55(395):205-212

Dong S, Jiang Y, Dong Y, Wang L, Wang W, Ma Z, Yan C, Ma C, Liu L (2019) A study on soybean responses to drought stress and rehydration. Saudi J Biol Sci 26(8):2006-2017

Evenari M, Schulze ED, Lange OL, Kappen L, Buschbom U (1976) Plant production in arid and semi-arid areas. In: Lange OL, Kappen L, Schulze ED (eds) Water and plant life. Ecological studies (analysis and synthesis), vol 19. Springer, Berlin, Heidelberg, pp 439-451

Farooq M, Nawaz A, Chaudhry MAM, Indrasti R, Rehman A (2017) Improving resistance against terminal drought in bread wheat by exogenous application of proline and gamma-aminobutyric acid. J Agron Crop Sci 203(6):464-472

Farooq M, Wahid A, Kobayashi N, Fujita D, Basra SMA (2009) Plant drought stress: effects, mechanisms and management. Agron Sustain Dev 29:185-212

Flexas J, Barón M, Bota J, Ducruet JM, Gallé A, Galmés J, Jiménez M, Pou A, Ribas-Carbó M, Sajnani C, Tomàs M, Medrano H (2009) Photosynthesis limitations during water stress acclimation and recovery in the drought-adapted Vitis hybrid Richter-110 (V. berlandieri $\mathrm{x}$ V. rupestris). J Exp Bot 60(8):2361-2377

Gai Z, Wang Y, Ding Y, Qian W, Qiu C, Xie H, Sun L, Jiang Z, Ma Q, Wang L, Ding Z (2020) Exogenous abscisic acid induces the lipid and flavonoid metabolism of tea plants under drought stress. Sci Rep 10(1): 12275

Giannakoula A, Moustakas M, Mylona P, Papadakis I, Yupsanis T (2008) Aluminum tolerance in maize is correlated with increased levels of mineral nutrients, carbohydrates and proline, and decreased levels of lipid peroxidation and $\mathrm{Al}$ accumulation. J Plant Physiol 165(4):385-396

Giardi MT, Cona A, Geiken B, Kučera T, Masojidek J, Mattoo AK (1996) Long-term drought stress induces structural and functional reorganization of photosystem II. Planta 199(1):118-125

Guo P, Baum M, Grando S, Ceccarelli S, Bai G, Li R, von Korff M, Varshney RK, Graner A, Valkoun J (2009) Differentially expressed genes between drought-tolerant and drought-sensitive barley genotypes in response to drought stress during the reproductive stage. J Exp Bot 60(12):3531-3544

Gupta S, Agarwal VP, Gupta NK (2012) Efficacy of putrescine and benzyladenine on photosynthesis and productivity in relation to drought tolerance in wheat (Triticum aestivum L.). Physiol Mol Biol Plants 18(4):331-336

Hertle AP, Blunder T, Wunder T, Pesaresi P, Pribil M, Armbruster U, Leister D (2013) PGRL1 is the elusive ferredoxin-plastoquinone reductase in photosynthetic cyclic electron flow. Mol Cell 49(3): $511-523$
Ioannidis NE, Kotzabasis K (2007) Effects of polyamines on the functionality of photosynthetic membrane in vivo and in vitro. Biochim Biophys Acta 1767(12):1372-1382

Ishibashi Y, Yamaguchi H, Yuasa T, Iwaya-Inoue M, Arima S, Zheng SH (2011) Hydrogen peroxide spraying alleviates drought stress in soybean plants. J Plant Physiol 168(13):1562-1567

Janack B, Sosoi P, Krupinska K, Humbeck K (2016) Knockdown of WHIRLY1 affects drought stress-induced leaf senescence and histone modifications of the senescence-associated gene HvS40. Plants $5(3): 37$

Khush GS (2001) Challenges for meeting the global food and nutrient needs in the new millennium. Proc Nutr Soc 60(1):15-26

Kura-Hotta M, Satoh K, Katoh S (1987) Relationship between photosynthesis and chlorophyll content during leaf senescence of rice seedlings. Plant Cell Physiol 28(7):1321-1329

Laxa M, Liebthal M, Telman W, Chibani K, Dietz KJ (2019) The role of the plant antioxidant system in drought tolerance. Antioxidants (Basel) 8(4):94

Lee S, Jeong H, Lee S, Lee J, Kim SJ, Park JW, Woo HR, Lim PO, An G, Nam HG, Hwang D (2017) Molecular bases for differential aging programs between flag and second leaves during grain-filling in rice. Sci Rep 7(1):8792

Lehtimäki N, Lintala M, Allahverdiyeva Y, Aro EM, Mulo P (2010) Drought stress-induced upregulation of components involved in ferredoxin-dependent cyclic electron transfer. J Plant Physiol 167(12):1018-1022

Li L, Aro EM, Millar AH (2018) Mechanisms of photodamage and protein turnover in photoinhibition. Trends Plant Sci 23:667-676

Li S, Li X, Wei Z, Liu F (2020) ABA-mediated modulation of elevated $\mathrm{CO}_{2}$ on stomatal response to drought. Curr Opin Plant Biol 56:174 180

Li XP, Xu QQ, Liao WB, Ma ZJ, Xu XT, Wang M, Zhu YC (2016) Hydrogen peroxide is involved in abscisic acid-induced adventitious rooting in cucumber (Cucumis sativus L.) under drought stress. J Plant Biol 59(5):536-548

Li Y, Zhao H, Duan B, Korpelainen H, Li C (2011) Effect of drought and $\mathrm{ABA}$ on growth, photosynthesis and antioxidant system of Cotinus coggygria seedlings under two different light conditions. Environ Exp Bot 71(1):107-113

Li Z, Zhou H, Peng Y, Zhang X, Ma X, Huang L, Yan Y (2015) Exogenously applied spermidine improves drought tolerance in creeping bentgrass associated with changes in antioxidant defense, endogenous polyamines and phytohormones. Plant Growth Regul 76(1):71-82

Lichtenthaler HK, Buschmann C, Knapp M (2005) How to correctly determine the different chlorophyll fluorescence parameters and the chlorophyll fluorescence decrease ratio $\mathrm{R}_{\mathrm{Fd}}$ of leaves with the PAM fluorometer. Photosynthetica 43(3):379-393

Lu J, Li XN, Yang YL, Jia LY, You J, Wang WR (2013) Effect of hydrogen peroxide on seedling growth and antioxidants in two wheat cultivars. Biol Plant 57(3):487-494

Martin A, Belastegui-Macadam X, Quilleré I, Floriot M, Valadier MH, Pommel B, Andrieu B, Donnison I, Hirel B (2005) Nitrogen management and senescence in two maize hybrids differing in the persistence of leaf greenness: agronomic, physiological and molecular aspects. New Phytol 167(2):483-492

Mattoo AK, Minocha SC, Minocha R, Handa AK (2010) Polyamines and cellular metabolism in plants: transgenic approaches reveal different responses to diamine putrescine versus higher polyamines spermidine and spermine. Amino Acids 38(2):405-413

Mega R, Abe F, Kim JS, Tsuboi Y, Tanaka K, Kobayashi H, Sakata Y, Hanada K, Tsujimoto H, Kikuchi J, Cutler SR, Okamoto M (2019) Tuning water-use efficiency and drought tolerance in wheat using abscisic acid receptors. Nat Plants 5(2):153-159

Melandri G, AbdElgawad H, Riewe D, Hageman JA, Asard H, Beemster G, Kadam N, Jagadish K, Altmann T, Ruyter-Spira C, Bouwmeester 
H (2020) Biomarkers for grain yield stability in rice under drought stress. J Exp Bot 71(2):669-683

Nikkanen L, Guinea Diaz M, Toivola J, Tiwari A, Rintamäki E (2019) Multilevel regulation of non-photochemical quenching and state transitions by chloroplast NADPH-dependent thioredoxin reductase. Physiol Plantarum 166(1):211-225

Pecio A, Wach D (2015) Grain yield and yield components of spring barley genotypes as the indicators of their tolerance to temporal drought stress. Polish J Agron 21:19-27

Pilarska M, Skowron E, Pietraś R, Krupinska K, Niewiadomska E (2017) Changes in lipid peroxidation in stay-green leaves of tobacco with senescence-induced synthesis of cytokinins. Plant Physiol Biochem 118:161-167

Pilarska M, Wiciarz M, Jajić I, Kozieradzka-Kiszkurno M, Dobrev P, Vanková R, Niewiadomska E (2016) A different pattern of production and scavenging of reactive oxygen species in halophytic Eutrema salsugineum (Thellungiella salsuginea) plants in comparison to Arabidopsis thaliana and its relation to salt stress signaling. Front Plant Sci 7:1179

Pottosin I, Shabala S (2014) Polyamines control of cation transport across plant membranes: implications for ion homeostasis and abiotic stress signaling. Front Plant Sci 5:154. https://doi.org/10.3389/fpls.2014. 00154

Sarker U, Oba S (2018) Catalase, superoxide dismutase and ascorbateglutathione cycle enzymes confer drought tolerance of Amaranthus tricolor. Sci Rep 8(1):16496

Sezgin A, Altuntaș C, Sağlam A, Terzi R, Demiralay M, Kadıŏlu A (2018) Abscisic acid cross-talking with hydrogen peroxide and osmolyte compounds may regulate the leaf rolling mechanism under drought. Acta Physiol Plant 40(8):141

Shabnam N, Tripathi I, Sharmila P, Pardha-Saradhi P (2016) A rapid, ideal, and eco-friendlier protocol for quantifying proline. Protoplasma 253(6):1577-1582

Shikanai T (2016) Chloroplast NDH: a different enzyme with a structure similar to that of respiratory NADH dehydrogenase. Biochim Biophys Acta Bioenerg 1857(7):1015-1022

Shu S, Yuan Y, Chen J, Sun J, Zhang W, Tang Y, Guo S (2015) The role of putrescine in the regulation of proteins and fatty acids of thylakoid membranes under salt stress. Sci Rep 5:14390

Sperdouli I, Moustakas M (2012) Spatio-temporal heterogeneity in Arabidopsis thaliana leaves under drought stress. Plant Biol 14(1): $118-128$

Sreenivasulu N, Graner A, Wobus U (2008) Barley genomics: an overview. Int J Plant Genomics 486258. https://doi.org/10.1155/2008/ 486258

Sun Y, Wang H, Liu S, Peng X (2016) Exogenous application of hydrogen peroxide alleviates drought stress in cucumber seedlings. S Afr J Bot 106:23-28

Suorsa M (2015) Cyclic electron flow provides acclimatory plasticity for the photosynthetic machinery under various environmental conditions and developmental stages. Front Plant Sci 6:800
Tamburino R, Vitale M, Ruggiero A, Sassi M, Sannino L, Arena S, Costa A, Batelli G, Zambrano N, Scaloni A, Grillo S, Scotti N (2017) Chloroplast proteome response to drought stress and recovery in tomato (Solanum lycopersicum L.). BMC Plant Biol 17(1):40

Tercé-Laforgue T, Mäck G, Hirel B (2004) New insights towards the function of glutamate dehydrogenase revealed during source-sink transition of tobacco (Nicotiana tabacum) plants grown under different nitrogen regimes. Physiol Plant 120(2):220-228

Terzi R, Kadioglu A (2006) Drought stress tolerance and the antioxidant enzyme system. Acta Biol Cracov Ser Bot 48:89-96

Terzi R, Kadioglu A, Kalaycioglu E, Saglam A (2014) Hydrogen peroxide pretreatment induces osmotic stress tolerance by influencing osmolyte and abscisic acid levels in maize leaves. J Plant Interact 9(1):559-565

Wan XY, Liu JY (2008) Comparative proteomics analysis reveals an intimate protein network provoked by hydrogen peroxide stress in rice seedling leaves. Mol Cell Proteomics 7(8):1469-1488

Wang H, Blakeslee JJ, Jones ML, Chapin LJ, Dami IE (2020) Exogenous abscisic acid enhances physiological, metabolic, and transcriptional cold acclimation responses in greenhouse-grown grapevines. Plant Sci 293:110437

Wellburn AR (1994) The spectral determination of chlorophylls $a$ and $b$, as well as total carotenoids, using various solvents with spectrophotometers of different resolution. J Plant Physiol 144(3):307-313

Xu PL, Guo YK, Bai JG, Shang L, Wang XJ (2008) Effects of long-term chilling on ultrastructure and antioxidant activity in leaves of two cucumber cultivars under low light. Physiol Plant 132(4):467-478

Yamburenko MV, Zubo YO, Vanková R, Kusnetsov VV, Kulaeva ON, Börner T (2013) Abscisic acid represses the transcription of chloroplast genes. J Exp Bot 64(14):4491-4502

Yao J, Sun D, Cen H, Xu H, Weng H, Yuan F, He Y (2018) Phenotyping of Arabidopsis drought stress response using kinetic chlorophyll fluorescence and multicolor fluorescence imaging. Front Plant Sci 9:603

Ying YQ, Song LL, Jacobs DF, Mei L, Liu P, Jin SH, Wu JS (2015) Physiological response to drought stress in Camptotheca acuminata seedlings from two provenances. Front Plant Sci 6:361. https://doi. org/10.3389/fpls.2015.00361

Zadoks JC, Chang TT, Konzak CF (1974) A decimal code for the growth stages of cereals. Weed Res 14(6):415-421

Zapata JM, Guéra A, Esteban-Carrasco A, Martín M, Sabater B (2005) Chloroplasts regulate leaf senescence: delayed senescence in transgenic ndhF-defective tobacco. Cell Death Differ 12(10):1277-1284

Zhang J, Jia W, Yang J, Ismail AM (2006) Role of ABA in integrating plant responses to drought and salt stresses. Field Crop Res 97(1): 111-119

Publisher's note Springer Nature remains neutral with regard to jurisdictional claims in published maps and institutional affiliations. 